\title{
Individual Privacy Interests and the "Special Needs" Analysis for Involuntary Drug and HIV Tests
}

\author{
Sean Anderson $\dagger$
}

Since the late 1980s, federal and state courts have addressed numerous Fourth Amendment challenges to government programs imposing mandatory blood or urine tests to detect the presence of drugs, alcohol, or the human immunodeficiency virus (HIV). Persons subject to such tests have included government employees, private employees in regulated industries, accused and convicted sex offenders, and accused and convicted prostitutes. Following the United States Supreme Court's lead, these courts have analyzed such testing programs using the "special needs" analysis, in which the program's intrusion upon Fourth Amendment interests is weighed against the governmental interest behind the testing, the necessity of the testing to that interest, and the procedural safeguards built into the testing program. This Comment contends that the special needs analysis affords courts too much discretion in balancing the various factors, thereby rendering each case a class by itself. At the same time, however, the special needs approach tends inexorably toward approving ever more intrusive drug and HIV testing programs, because it assigns excessive importance to the governmental interests asserted to justify testing, credits too easily government arguments concerning the necessity of testing to serve those interests, and allows procedural regularity in the imposition of tests to substitute for substantive protection against the intrusion the tests embody. As a result of these shortcomings, the author proposes an analysis that looks primarily at the blameworthiness of the conduct or status

Copyright $\odot 1998$ California Law Review, Inc.

i Law Clerk to the Honorable Walter J. Cummings, U.S. Court of Appeals for the Seventh Circuit; J.D., Boalt Hall School of Law (University of California-Berkeley), 1997; B.A., Bucknell University, 1989. 1 thank Professor Rachel Moran for her able and penetrating criticism during this Comment's development. My gratitude also goes to the members of the California Law Review, particularly Tom Ginsburg, Randy Keen, and Sherri Sokeland, for helping to clean up after my errors and leaps in logic. The remaining flaws are likely the result of my not following these people's advice consistently enough. Special thanks to my family, from whom all that 1 am has come, and to Johna, my only love. 
that would trigger drug or HIV testing. Such an approach, the author argues, would better protect the individual interests that the Fourth Amendment ought properly to defend.

\section{INTRODUCTION}

The Fourth Amendment to the United States Constitution protects individuals against "unreasonable searches and seizures"1 conducted pursuant to government authority. ${ }^{2}$ This Comment examines the method by which courts have determined whether certain categories of searches are "reasonable" or not. Those searches involve blanket blood or urine tests designed to detect the presence of alcohol, drugs, or $\mathrm{HIV}$, the virus that causes AIDS. This Comment contends that the analysis under which the United States Supreme Court and other courts have evaluated such searches is fatally flawed. It fails to account for vast factual differences among the many contexts in which suspicionless testing takes place, and it tends inexorably to approve of invasions upon the privacy interests the Fourth Amendment ought to protect.

The current United States Supreme Court approach is drawn primarily from two 1989 decisions, Skinner v. Railway Labor Executives' Association $^{3}$ and National Treasury Employees Union v. Von Raab. ${ }^{4}$ These cases held that the federal governinent could require suspicionless drug and alcohol tests of certain employees in the railroad industry and the United States Customs Service. The Court reached these results by applying a Fourth Amendinent analysis known as the "special needs" test, which it had previously used to approve warrantless searches of property that were based upon a "reasonable" level of suspicion." Skinner and Von Raab extended the application of the special needs analysis in two important ways. First, they applied it to intrusions into the human body rather than to searches of property. Second, the cases upheld searches of entire categories of persons in the absence of any suspicion that particular individuals were in fact using drngs or alcohol. ${ }^{6}$

The special needs analysis proceeds by balancing the governmental interests served by the testing against the constitutional freedoms the

1. U.S. Const. amend. IV.

2. See Chandler v. Miller, 117 S. Ct. 1295, 1305 (1997) (referring to "drug testing in the private sector" as "a domain unguarded by Fourth Amendment constraints").

3. 489 U.S. 602 (1989).

4. 489 U.S. 656 (1989).

5. See, e.g., Griffin v. Wisconsin, 483 U.S. 868 (1987) (upholding search of probationer's apartment for weapons); O'Connor v. Ortega, 480 U.S. 709 (1987) (upholdung search of government employee's office for papers).

6. In Von Raab, there was not even evidence that drug use existed among the class of employees subject to testing. See Von Raab, 489 U.S. at 673. Justices Scalia and Stevens, who had both joined the majority in Skinner, dissented in Von Raab for this very reason. See id. at 680-81 (Scalia, J., dissenting). 
search invades.? If a court finds that the government's interests are sufficient to justify the invasion of individual freedoms, it must uphold the search. The Supreme Court has held that the analysis is appropriate when the search is designed to serve governmental needs "beyond the normal need for law enforcement," and when a stricter requirement, such as a warrant, would frustrate the achievement of these governmental purposes. ${ }^{9}$

In the years since Skinner and Von Raab, the Supreme Court has revisited the special needs analysis only twice, first approving a school district's drug testing program for high school athletes, ${ }^{10}$ and more recently striking down a drug testing requirement for candidates for state offices in Georgia." Lower courts, however, have used the special needs approach to analyze any number of government-imposed blood and urime tests. These tests have been designed to detect either drug use or HIV infection and have been directed at such diverse groups as accused and convicted sex offenders, ${ }^{12}$ public employees, ${ }^{13}$ private employees in regulated industries, ${ }^{14}$ persons involved in traffic accidents, ${ }^{15}$ convicted prostitutes, ${ }^{16}$ and persons involved in physical struggles with police officers. ${ }^{17}$

While a few cases have found testing schemes unjustified under the special needs rationale, ${ }^{18}$ the broad tendency of the analysis has been to

7. See Skinner, 489 U.S. at 619.

8. Griffin, 483 U.S. at 873 (citing New Jersey v. T.L.O., 469 U.S. 325, 351 (1985) (Blackmun, J., concurring in judgment)).

9. See Skinner, 489 U.S. at 623-24.

10. See Vernonia School Dist. 47J v. Acton, 115 S. Ct. 2386 (1995).

11. See Chandler v. Miller, 117 S. Ct. 1295 (1997).

12. See, e.g., Rise v. Oregon, 59 F.3d 1556 (9th Cir. 1995); Virgin Islands v. Roberts, 756 F. Supp. 898 (D.V.I. 1991); Fosman v. State, 664 So. 2d 1163 (Fla. Dist. Ct. App. 1995); State ex rel. J.G., 674 A.2d 625 (N.J. Super. Ct. App. Div. 1996); In re Juveniles A,B,C,D,E, 847 P.2d 455 (Wash. 1993).

13. See, e.g., Taylor v. O'Grady, 888 F.2d 1189 (7th Cir. 1989); Harmon v. Thomburgh, 878 F.2d 484 (D.C. Cir. 1989); Anonymous Fireman v. City of Willoughby, 779 F. Supp. 402 (N.D. Ohio 1991).

14. See, e.g., Dimeo v. Griffin, 943 F.2d 679 (7th Cir. 1991); Bluestein v. Skinner, 908 F.2d 451 (9th Cir. 1990).

15. See, e.g., Fink v. Ryan, 673 N.E.2d 281 (Ill. 1990); State v. Roche, 681 A.2d 472 (Me. 1996).

16. See, e.g., Love v. Superior Court, 276 Cal. Rptr. 660 (Cal. Ct. App. 1990); People v. Adams, 597 N.E.2d 574 (III. 1992).

17. See, e.g., Johnetta J. v. San Francisco Mun. Court, 267 Cal. Rptr. 666 (Cal. Ct. App. 1990). In addition to the groups of persons mentioned in the text, at least one case has upheld mandatory HIV testing (and disclosure of the results) for persons convicted of unauthorized possession of a hypodermic needle or syringe. See People v. C.S., 583 N.E.2d 726 (IIl. App. Ct. 1991).

18. See, e.g., Harmon v. Thomburgh, 878 F.2d 484 (D.C. Cir. 1989) (rejecting Department of Justice random drug testing program when apphied to employees lacking top secret clearances); Beattie v. City of St. Petersburg Beach, 733 F. Supp. 1455 (M.D. Fla. 1990) (rejecting suspicionless drug testing of firefighters). 
validate even very extensive testing programs. ${ }^{19}$ One commentator has argued that the analysis is structurally predisposed toward approving intrusive testing schemes, because it weighs broadly stated governmental interests against the privacy of a few individuals. ${ }^{20}$

This Comment agrees with the latter complaint and argues that the special needs analysis is flawed for two further reasons. First, it leads courts to give too much credence to governmental assessments of whether a particular testing scheme is necessary to serve the interests invoked to justify it. Second, it allows courts to accept procedural protections in the administration of drug and HIV tests as a substitute for substantive protection against such invasions.

The end result of these three flaws is that the special needs analysis simply cannot deal satisfactorily with the fundamentally different factual contexts in which it is currently applied. The expansion of the analysis to justify such a wide variety of intrusions is unwarranted. In the formless balancing of interests, the most profound ideas of individual privacy become mere currency to be traded off against governmental imperatives and procedural regularity. This Comment argues that this situation is dangerous and undesirable, and that Fourth Amendment analysis must give much higher priority to the individual interests that the Ainendment seems on its face to protect.

This Comment does not offer an extensive historical or textual analysis of the Fourth Amendment. Rather, its starting premise is that, in the complex interaction between government and governed, it is most often the governed who stand in need of protection. ${ }^{21}$ It should not be the primary task of Fourth Ainendinent analysis, therefore, to identify those searches and seizures that are necessary or convenient for the agencies of government. ${ }^{22}$ Judicial analysis of searches and seizures should seek flrst and always to defend individuals against intrnsion by an overzealous government. ${ }^{23}$

19. See, e.g., Taylor v. O'Grady, 888 F.2d 1189 (7th Cir. 1989); American Fed'n of Gov't Employees v. Skinner, 885 F.2d 884 (D.C. Cir. 1989).

20. See Kenneth Nuger, The Special Needs Rationale: Creating a Chasm in Fourth Amendment Analysis, 32 Santa Clara L Rev. 89, 131 (1992) (stating that "[i]ndividual privacy claims will inevitably lose [the special needs] balancing test, for it is rare when individual behavior is perceived as more important than the burdens forced on the public by the cumulative effect of the individual behavior").

21. See Anthony G. Amsterdam, Perspectives on the Fourth Amendment, 58 MinN. L. Rev. 349,400 (1974) (noting that the Framers of the Bill of Rights "feared what a powerful central government might bring, not only to the jeopardy of the states but to the terror of the individual").

22. See id. at 354 ("[T] he history of the destruction of liberty ... has largely bcen the history of the relaxation of [procedural] safeguards in the face of plausible-sounding governmental claims of a need to deal with widely frightening and emotion-freighted threats to the good order of society.").

23. See, e.g., Watts v. Indiana, 338 U.S. 49, 61 (1949) (Jackson, J., concurring) (stating that the Bill of Rights places "the maximum restrictions upon the power of organized society over the individual that are compatible with the maintenance of organized society itself'). This is hardly an 
This Comment advocates an approach to mandatory drug and HIV testing programs that separates out the individual interests at stake and elevates them to a position of priority. It does so by treating as a threshold issue the question of whether the class of persons to be tested has done anything that society considers blameworthy. Under this approach, no balancing or other consideration of the government interests behind testing, the necessity of testing to those purposes, or the procedural protections included in a testing program can take place until a court has determined that the persons to be tested have acted in a way that legitimately subjects them to the intrnsion of testing. That is, the analysis requires a court to look first at the blameworthiness of the acts that define the class of persons to be tested. If those persons are made subject to testing without their having done anything blameworthy, the analysis requires the court to strike down the program as unconstitutional. Only if the class of persons has done something that society considers blameworthy can the court balance the interests at stake to decide whether testing is appropriate. In such cases, the severity of the blameworthy action will influence the analysis of whether the testing program is justified. More serious actions by the persons to be tested will render testing easier for the government to defend, while less blameworthy acts will require higher levels of judicial scrntiny.

Part I of this Comment traces the developinent of the special needs doctrine in Supreme Court cases. Part II describes many of the lower court cases decided since 1989. Part III presents a critique of the special needs analysis, focusing on its overly charitable treatment of governmental claims of necessity and its acceptance of procedural regularity as a proxy for real privacy protection. Part IV describes an alternative approach to Fourth Amendment analysis of involuntary blood and urine tests in various contexts, an approach that takes as its organizing principle an assessment of the blameworthiness of the action that triggers testing.

The Deterioration of Fourth Amendment Protections

The Fourth Amendment to the United States Constitution provides that

The right of the people to be secure in their persons, houses, papers, and effects, against unreasonable searches and seizures,

unusual view of the Fourth Amendment. See, e.g., Tracey Maclin, The Central Meaning of the Fourth Amendment, 35 WM. \& MARY L. REv. 197 (1993). Writing in the context of criminal searches, Maclin argues that the Fourth Amendment is "a reminder to all of us that the Constitution places our individual interests in privacy, personal security, and human dignity on a higher plane than society's interest in catching criminals." Id. at 201 n.16. 
shall not be violated, and no Warrants shall issue, but upon probable cause, supported by Oath or affirmation, and particularly describing the place to be searched, and the persons or things to be seized. ${ }^{24}$

In general, the Supreme Court has interpreted these words to mean that a governmental intrusion into an individual's reasonable expectations of privacy ${ }^{25}$ must be authorized by a judicial warrant based upon probable cause. ${ }^{26}$ Probable cause, in turn, refers to a fair probability that the persons performing a search will find the evidence they seek in the particular place to be searched. ${ }^{27}$

Over the past several decades, however, the Court has upheld searches in a wide array of cases in which a warrant, probable cause, or both were absent. The seeds of this drastic loosening of Fourth Amendment standards lie in cases that stake out carefully limited exceptions to the warrant requirement. The most extreme outgrowths of this approach, however, embrace wide authorizations for invasive searches in a variety of contexts, performed without any individualized suspicion that the evidence sought is present.

\section{A. Before the Special Needs Test}

\section{Traditional Exceptions}

Historically, the Fourth Amendinent's Warrant Clause governed searches and seizures conducted on government authority. ${ }^{28}$ The Supreme Court recognized a few narrow exceptions to the warrant requirement. For instance, police could search a person and her immediate surroundings in connection with a lawful arrest of that person, ${ }^{29}$ and they could enter private property while in immediate pursuit of a

24. U.S. CONST. amend. IV.

25. See Katz v. United States, 389 U.S. 347, $351-53$ (1967) (detaching Fourth Amendment protection from strict ideas of private property); id. at 361 (Harlan, J., concurring) (delineating areas of protection as those in which one has both a subjective and an objectively reasonable expectation of privacy).

26. See, e.g., Winston v. Lee, 470 U.S. 753, 759 (1985).

27. See Illinois v. Gates, 462 U.S. 213, 238 (1983). Gates cites, among other cases, Brinegar v. United States, 338 U.S. 160 (1949), which defines the probable cause needed to arrest a person as "less than evidence which would justify condemnation or conviction," but "more than bare suspicion." Id. at 175 (citation omitted). More particularly, "[p]robable cause exists where "the facts and circumstances within ... [the officers'] knowledge ... [are] sufficient in themselves to warrant a inan of reasonable eaution in the belief that' an offense has been or is being committed." Id. at 175-76 (quoting Carroll v. United States, 267 U.S. 132, 162 (1925)).

28. See Schmerber v. California, 384 U.S. 757, 770 (1966) (noting that both probable cause and a search warrant "are ordinarily required" for searches of dwellings and intrusions upon the body).

29. See Preston v. United States, 376 U.S. 364, 367 (1964); Agnello v. United States, 269 U.S. 20,30 (1925). 
suspect. ${ }^{30}$ These exceptions, both founded upon the need of officers to protect themselves against hidden weapons and to secure evidence against imminent destruction, ${ }^{31}$ assumed the existence of probable cause to support the pursuit or arrest. ${ }^{32}$

In addition, the Court condoned warrantless searches based upon probable cause $\mathrm{m}$ situations in which the delay of securing a warrant would be likely to result im the destruction of evidence. For instance, in Schmerber v. California, Justice Brennan held for the Court that a police officer could compel a person whom he had probable cause to believe had been driving while intoxicated to submit to a warrantless bloodalcohol test. ${ }^{33}$

Since the mid-1960s, the Court has dramatically broadened the range of circumstances that allow a departure from the warrant requirement. In addition, it has held in a number of cases that certain searches do not even require probable cause. In general, it has done so by reading the Warrant Clause as applying only to a limited set of search and seizure cases, and by relying on the much broader language of the Amendment's "reasonableness" requirement to determine which cases do-or do not-require a warrant. ${ }^{34}$

Perhaps inevitably, this focus on reasonableness has led the Court to a mostly ad hoc investigation of the circumstances of each case under a broad "balancing" analysis. If strict categorical requirements such as a warrant are not universally applicable, then each situation will yield its own unique assessment of reasonableness. Judicial discretion will determine the weight given to individual liberty interests and to governmental interests such as health and safety.

\section{Administrative Searches}

The ad hoc balancing approach made an early appearance in 1967 in the context of housing inspections. In Camara v. Municipal Court, the Court retreated from an earlier case that held that such administrative inspections were at most "peripheral" Fourth Amendment intrusions. ${ }^{35}$ By requiring warrants for nonconsensual administrative searches, the decision actually broadened Fourth Amendment warrant protections.

30. See Warden v. Hayden, 387 U.S. 294, 298-99 (1967).

31. See id.; Preston, 376 U.S. at 367.

32. See Hayden, 387 U.S. at 307; Preston, 376 U.S. at 367-68 (emphasizing that the arrest must be lawful-i.e., based on probable cause-in order to justify a search).

33. See Schmerber, 384 U.S. at 766-72.

34. See, e.g., id. at 768 (framing the question for adjudication as whether the search "respected relevant Fourth Amendment standards of reasonableness"). For a more recent example, see Skinner v. Railway Labor Executives' Ass' $n$, 489 U.S. 602, 619 (1989) (stating that "the Fourth Amendment does not proscribe all searches and seizures, but only those that are unreasonable").

35. 387 U.S. 523, 530 (1967) (overruling Frank v. Maryland, 359 U.S. 360 (1959)). 
The Court also held, however, that warrants authorizing such searches need not rest upon the probability that a particular dwelling is in violation of an administrative standard. Instead, the Court required only that an administrative search warrant be issued pursuant to a program implementing "reasonable legislative or administrative standards for conducting an area inspection." 36 Due to the Warrant Clause's explicit language, however, the Court was compelled to refer to this set of legislative or administrative standards as "probable cause."37 The Court reached this odd result by distinguishing the governmental interest in conducting housing inspections from that involved in the criminal context. ${ }^{38}$ The interest in securing compliance with housing codes, the Court believed, requires for its attainment "routine periodic inspections of all structures." ${ }^{39}$ Moreover, because the inspectious are not "aimed at the discovery of evidence of crime, they involve a relatively limited invasion of the ... citizen's privacy."40

Thus, the Court in Camara embraced a balancing approach in which the governmeutal interest served by the search is weighed against the intrusion upon the individual's protected interests. ${ }^{41}$ The Court has continued to apply this balancing analysis in subsequent administrative search cases, including those in which it has held warrants unnecessary. Wheu a certain area of business or iudustry is "pervasively"42 or "closely regulated," 43 the Court has held that owners and operators have "no reasouable expectation of privacy."

\section{The Requirement of Reasonable Suspicion}

While the administrative search cases used balancing to redefine probable cause, another line of cases explicitly retreated from the necessity of either a warrant or probable cause. In Terry $v$. Ohio, a police officer "frisked" a suspect for weapons after he observed the man and two companions acting suspiciously near a storefront. ${ }^{45}$ The Court held that the officer could conduct such a limited search even though he had

36. Id. at 538. "Such standards," the Court continued, "... may be based upon the passage of time, the nature of the building (e.g., a multi-family apartment house), or the condition of the entire area...." Id.

37. Id.

38. See id. at 534-35.

39. Id. at 535-36.

40. Id. at 537.

41. See id. at 536-37.

42. United States v. Biswell, 406 U.S. 311, 316 (1972).

43. Colonnade Catering Corp. v. United States, 397 U.S. 72, 74 (1970).

44. Marshall v. Barlow's, Inc., 436 U.S. 307, 313-15 (1978) (noting exception for regulated businesses but holding it inapplicable to electrical and plumbing installation company). For a discussion of administrative search cases decided after the advent of the "special needs" rubric, see infra text accompanying notes 75-90.

45. 392 U.S. 1 (1968). 
no probable cause to believe that the individual was guilty of a crime. ${ }^{46}$ The Court in Terry cited approvingly the balancing approach adopted in Camara $^{47}$ and applied it to reach the conclusion that such a search is justified as long as the officer can "point to specific and articulable facts which, taken together with rational inferences from those facts, reasonably warrant that intrusion." In other words, so long as the officer had a reasonable and articulable suspicion that the suspect was carrying a weapon, he was authorized to "pat him down." The Terry Court took pains to limit this principle to searches for weapons, since their reason for adopting it was to allow police officers to guard their own safety and that of others. ${ }^{49}$

Despite this limiting language, the Court seven years later cited both Terry and Camara in extending the reasonable suspicion principle to "roving stops" of cars by the Border Patrol.50 Pointing to both the vital public interest in preventing illegal immigration and the "limited nature of the intrusion" involved, the Court held that roving stops "may be justified on facts that do not anount to the probable cause required for arrest." 51 Although the Court found that the particular roving Border Patrol stop in question, which was based only on the apparent Mexican ancestry of the car's occupants, was unconstitutional, ${ }^{52}$ its holding applied the reasonable suspicion standard in a context far removed from the "stop-and-frisk" weapons search in Terry.

In 1979, the Court further expanded the scope of the reasonable suspicion standard in Delaware v. Prouse $e^{53}$ by using it to evaluate a policeman's decision to stop a car and check the driver's license and vehicle registration. In affirming the suppression of drug evidence seized during such a stop, the Court held that an officer must have "at least articulable and reasonable suspicion" that either the driver or the vehicle is in violation of some licensing requirement or other law. ${ }^{54}$ Once again, the Court grounded this departure from the warrant and probable cause requirements upon its prior holdings: It cited Camara for the principle of balancing and then analogized traffic stops to the border stops in Brignoni-Ponce and to the weapons frisks in Terry. ${ }^{55}$

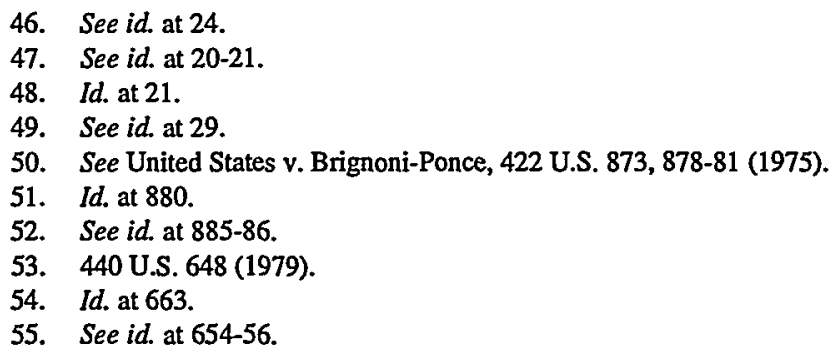




\section{An Apparent Anomaly: The Suspicionless Search}

In the midst of its development of the administrative warrant and reasonable suspicion cases, the Court decided United States $v$. Martinez-Fuerte. ${ }^{56}$ There, the Court evaluated the Border Patrol's use of highway checkpoints to look for undocumented aliens well away from the border itself." ${ }^{57}$ Border Patrol agents at the checkpoints stopped all vehicles briefly and then directed a smaller number of vehicles to pull aside for further questioning. ${ }^{58}$ The Court distinguished this kind of checkpoint stop from the roving stops at issue in Brignoni-Ponce by finding that they did not present as great an intrusion upon motorists' protected interests. ${ }^{59}$ Then, on the basis of this distinction, the Court held that the checkpoint stops and questioning were legitimate even "in the absence of any individualized suspicion." 60 Perhaps most shockingly, the Court acknowledged that its decision made constitutional referrals for questioning "made largely on the basis of apparent Mexican ancestry." The Court in Martinez-Fuerte further refused to adopt a warrant requirement for the checkpoints theinselves, rejecting even the generalized imspection warrant approach it took in Camara. ${ }^{62}$ Again, the Court cited the minimal nature of the intrusion as well as the reassurance that motorists would receive from knowing that everyone else on the road was subject to the checkpoint stop as well. ${ }^{63}$

Martinez-Fuerte represents an apparent anomaly in the context of the cases described earlier. It is tempting to explain this anomaly by reference to the fact that the governmental aim in this case was to protect the country's borders, which the Court has consistently found to be an especially vital goal. ${ }^{64}$ The stops in Brignoni-Ponce, however, also took place near the border and aimed to protect it from the same threat, and yet there the Court demanded reasonable suspicion. ${ }^{65}$ Moreover, the Court im 1990 used Martinez-Fuerte as authority to uphold checkpoint stops designed to apprehend drunk drivers, a goal clearly having no connection to protecting international borders. ${ }^{66}$ In any event, the

56. 428 U.S. 543 (1976).

57. See id. at 545,550 (noting that the two checkpoints involved were, respectively, 66 and 65 . 90 miles from the Mexican border).

58. See id. at 546 .

59. See id. at 562-64.

60. Id. at 562 .

61. Id. at 563 .

62. See id. at 564-66.

63. See id. at 565 .

64. See, e.g., United States v. Montoya de Hernandez, 473 U.S. 531,537 (1985).

65. See United States v. Brignoni-Ponce, 422 U.S. 873, 884-85 (1975).

66. See Michigan Dep't of State Police v. Sitz, 496 U.S. 444, $451-55$ (1990). 
Court's abandonment of even a reasonable suspicion requirement provided precedent for its later employment drug testing cases. ${ }^{67}$

\section{B. The Special Needs Analysis}

\section{Special Needs Makes Its Debut}

In 1985, a new catch phrase began to appear in Supreme Court opinions to describe the range of contexts in which the warrant and probable cause requirements would not apply. The phrase was "special needs," and it first appeared in Justice Blackmun's concurring opinion in New Jersey v. T.L.O. ${ }^{68}$ In that case, the Court held that a school official's search of a high school student's purse could be justified by "reasonable grounds for suspecting that the search will turn up evidence" of a violation of school rules or of the law. ${ }^{69}$ Because the search at issue was supported by such grounds, and because its scope was "reasonably related" to the legitimate goal of seeking evidence, the Court upheld the procedure as constitutional. ${ }^{70}$

In his concurring opinion, Justice Blackmun sought to narrow the Court's holding by characterizing the high school context as a peculiar one in which a departure from the Warrant Clause in favor of balancing was appropriate. He stated that "[o]nly in those exceptional circumstances in which special needs, beyond the normal need for law enforcement, make the warrant and probable-cause requirement impracticable, is a court entitled to substitute its balancing of interests for that of the Framers." 71 He then described the holdings in Terry, Brignoni-Ponce, Martinez-Fuerte, and Camara as resting upon the impracticability of requiring warrants and/or probable cause and explained more fully why the high school setting presented similar considerations. $^{72}$

From the majority's standpoint, as well as that of the dissenters, T.L.O. was merely another in the line of reasonable suspicion cases that began with Terry. ${ }^{73}$ While Justice Blackmun also placed the case in that context, he sought to rein in the Court's tendency to make balancing "the rule rather than the exception." That attempt has not been very

67. See National Treasury Employees Union v. Von Raab, 489 U.S. 656 (1989); Skinner v. Railway Labor Executives' Ass'n, 489 U.S. 602, 624 (1989). The drug testing cases are discussed in Part I.B.3 infra.

68. 469 U.S. 325,351 (1985).

69. Id. at 342 .

70. See id. at $342,347-48$.

71. Id. at 351 .

72. See id. at $352-53$.

73. See id. at 369 (Brennan, J., concurring in part and dissenting in part); id. at 376-77 (Stevens, $\mathrm{J}$., concurring in part and dissenting in part).

74. Id. at 352 . 
successful, in large part because the language of the special needs formulation is so general and adaptable.

\section{Special Needs Becomes Court Doctrine}

Later in the same Term, the Court applied the balancing approach in a case involving the protracted detention of a woman suspected of swallowing balloons full of cocaine in order to sunuggle them into the United States. ${ }^{75}$ While the Court's opinion, in which Justice Blackmun joined, did not adopt the special needs formulation, it did take pains to characterize the protection of international borders as an unusually vital governmental interest. ${ }^{76}$

Having found that the balance between individual privacy and liberty interests and the need to search to protect the integrity of the border tipped strongly in the government's favor, the Court went on to hold that customs agents may search travelers on the basis of reasonable suspicion. ${ }^{7}$ The suspicion in this case was based on the fact that the woman arrived in Los Angeles from Bogota with one small valise, $\$ 5,000$ in cash, and a passport showing frequent trips to Miami and Los Angeles. ${ }^{78}$ Even though the woman was detained for more than sixteen hours and ordered to defecate in a bucket with an agent watching her, the Court held that her rights were not violated. ${ }^{79}$

In 1987, a majority of the Court explicitly adopted the special needs formulation in three cases that illustrate the chameleon-like character of the doctrine. First, in $O^{\prime}$ Connor $v$. Ortega, the Court addressed a supervisor's search of a state-employed doctor's office, which included the seizure of personal iteins. ${ }^{80}$ The search took place while hospital officials were investigating the doctor for various "possible improprieties." ${ }^{31}$ The hospital claimed that it conducted the search to "secure state property," 82 but material seized in the search was later used against the doctor in administrative proceedings that led to his discharge from employment. ${ }^{83}$

75. See United States v. Montoya de Hernandez, 473 U.S. 531 (1985).

76. See id. at 537-39 \& n.l (citing, inter alia, Carroll v. United States, 267 U.S. 132, 154 (1925) (recognizing the need for "national self protection reasonably requiring one entering the country to identify himself as entitled to come in and his belongings as effects which may be lawfully brought in")).

77. See id. at 539-41.

78. See id. at 533-34.

79. See id. at 544; see also id. at $545-48$ (Brennan, J., dissenting) (describing in detail tbe impositions upon respondent).

80. 480 U.S. 709,713 (1987).

81. Id. at 712 .

82. Id. at 713.

83. See id. at 713-14. 
In addressing the constitutionality of the search, five Justices adopted the special needs formulation from T.L.O. as a description of the kind of circumstance in which the Warrant Clause is not applicable. ${ }^{84}$ While the plurality and the concurrence reached different conclusions regarding the appropriate non-warrant standard to be applied, ${ }^{85}$ they agreed that the government employment context presented needs "different from "the normal need for law enforcement," those special needs determine when the warrant and probable cause requirements are inappropriate. ${ }^{87}$

In the second case, New York v. Burger, the Court upheld a search of an automobile junkyard on the strength of the previously recognized exception for "closely regulated" industries. ${ }^{88}$ Even though the search had as its purpose the detection of junkyards that trafficked in stolen cars and parts, the Court rejected the claim that it was really a criminal matter with only pretextual administrative trappings. ${ }^{89}$ In so doing, the Court took care to integrate the Camara line of administrative cases with the newer terminology of special needs. It characterized heavily regulated business settings as exhibiting the kind of special needs to which Justice Blackmun referred in T.L.O. ${ }^{90}$ Thus, the Court subsumed an older exception to the Warrant Clause under the expansive umbrella of special needs.

Finally, in Griffin v. Wisconsin, the Court found that a state's special need to supervise its probation system justified subjecting probationers to "a degree of impingement upon privacy that would not be constitutional if applied to the public at large."91 Specifically, the search of a probationer's home for weapons could be justified by "reasonable grounds" that clearly did not amount to probable causein this case, the "unauthenticated tip of a police officer." the Court used the rationale of special needs in an explicitly criminal context, to uphold a thorough search of a private home.

84. See id. at $\mathbf{7 2 0}$ (plurality opinion); id. at 732 (Scalia, J., concurring in judgment).

85. See id. at 726 (plurality opinion) (holding that a search by a supervisor is "[o]rdinarily" justified by "reasonable grounds for suspecting" either that it will reveal evidence of "work-related misconduct" or that it is "necessary for a noninvestigatory work-related purpose such as to retrieve a needed file"); id. at 732 (Scalia, J., concurring in judgment) (asserting flatly that searches with workrelated goals "do not violate the Fourth Amendment").

86. Id. at 724 (plurality opinion) (citation omitted); accord id. at 732 (Scalia, J., concurring in judgment).

87. See id. at 722-25; id. at 732 (Scalia, J., concurring in judgment) (stating that "special needs" of public employment context mean warrantless search did not violate Fourth Amendment).

88. 482 U.S. 691, 703-07 (1987); see also supra notes $42-44$ and accompanying text.

89. See Burger, 482 U.S. at 712-16; infra notes 253-254 and accompanying text.

90. See Burger, 482 U.S. at 702.

91. 483 U.S. 868,875 (1987).

92. Id. at $875-76,878$. 


\section{Suspicionless Searches: The Employment Drug Testing Cases}

Under the then firmly entrenched special needs doctrine, the Court in 1989 resurrected the idea of suspicionless searches that had lain dormant during the thirteen years since Martinez-Fuerte. ${ }^{93}$ A pair of cases in that year, Skinner v. Railway Labor Executives' Association ${ }^{94}$ and National Treasury Employees Union v. Von Raab, ${ }^{95}$ involved government-imposed drug tests of einployees, one in private railroads and the other in the U.S. Customs Service. In neither case did the testing programs require any kind of individualized suspicion that the employees to be tested were using drugs. ${ }^{96}$

In finding both testing schemes constitutional, the Court went to great lengths to emphasize the importance of the special government needs that they served. For instance, in Skinner the Court noted that "employees who are subject to testing under the [Federal Railroad Administration] regulations can cause great human loss before any signs of impairment become noticeable to supervisors or others."97 Similarly, the Court in Von Raab defended the use of tests on Customs Service officials involved in drug interdiction by asserting that the "national interest in self-protection could be irreparably damaged if those charged with safeguarding it were, because of their own drug use, unsympathetic to their mission of interdicting narcotics. ${ }^{993}$

On the other side of the special needs balancing test, the Court downplayed the intrusion upon employees' privacy. In Skinner, for instance, the Court found that blood and urine tests were not uncommon procedures in medical contexts and therefore did not represent significant intrusions. ${ }^{99}$ In addition, the Court in Skinner held that employees in industries that are "regnlated pervasively to ensure safety" are not entitled to the same "expectations of privacy" as other citizens. ${ }^{100}$ In effect, though not explicitly, this decision analogized the drug tests at issue to the administrative searches in such cases as New York $v$.

93. See United States v. Martinez-Fuerte, 428 U.S. 543 (1976); supra notes 56-67 and accompanying text.

94. 489 U.S. 602 (1989) (addressing drug and alcohol testing of railroad employees undcr regulations promulgated by the Federal Railroad Administration).

95. 489 U.S. 656 (1989) (addressing drug testing of certain Customs Service employees).

96. See Skinner, 489 U.S. at 609-11; Von Raab, 489 U.S. at 660-61.

97. Skinner, 489 U.S. at 628.

98. Von Raab, 489 U.S. at 670 . Note that the testing scheme in Von Raab also covered employees seeking positions in which they would carry firearms or handle classified material. The Court approved the policy for drug interdiction and firearms positions, and remanded for further factfinding as to what materials would count as "classified." See id. at 677-79.

99. See Skinner, 489 U.S. at 625 (citing, with regard to blood tests, Schmerber v. Califomia, 384 U.S. 757, $771(1966))$.

100. Id. at 627 . 
Burger. ${ }^{101}$ That is, a principle that previously held the premises of certain kinds of businesses subject to health inspections and the like was extended to justify compelled collection and testing of the bodily fluids of persons who took jobs in certain industries. Having thus minimized the privacy expectations of railroad employees in Skinner, the Court in Von Raab had little difficulty doing the same for customs agents, who are after all direct employees of the government itself, involved in protecting the country's borders against the importation of contraband. ${ }^{102}$

Moreover, just as Justice Blackmun in T.L.O. had declared the warrant requirement to be "impracticable" under the circumstances, ${ }^{103}$ in these two cases the Court found even individualized suspicion to be too demanding a requirement. "[W] $]$ here an important governmental interest furthered by the intrusion would be placed in jeopardy by a requirement of individualized suspicion, a search may be reasonable despite the absence of such suspicion." 104 In Skinner, for instance, the Court found that "[a]n impaired employee... will seldom display any outward 'signs detectable by the lay person or, in many cases, even the physician." 105 For this reason, requiring individualized suspicion would allow drug-or alcohol-impaired workers to continue at their jobs.

With Skinner and Von Raab, the Court held that the government is authorized to carry out what it judges to be the most effective plan for attaining its interest, so long as the privacy interests invaded can be characterized as "minimal" for the kinds of reasons discussed above. ${ }^{106}$ After these cases, what amounts to a blanket warrant for drng testing is constitutional in a vaguely delineated set of circumstances. Perhaps just as importantly, the Court gave its blessing to the special needs analysis as the proper approach for all cases involving plans for blood or urine tests. This aspect of the holdings set off a series of lower court decisions attempting to apply the special needs formulation to a bewildering variety of situations. This Comment will turn to those cases after a brief look at the most recent Supreine Court drug testing decisions.

\section{Recent Cases: Vernonia and Chandler}

In 1995, the Supreme Court applied the special needs framework to uphold mandatory urinalysis drug tests of high school athletes. ${ }^{107}$ The Court first declared that high school students, and student-athletes in

101. 482 U.S. 691 (1987); see supra notes $88-90$ and accompanying text.

102. See Von Raab, 489 U.S. at 672.

103. New Jcrsey v. T.L.O., 469 U.S. 325, 351 (1985) (Blackmun, J., concurring).

104. Skinner, 489 U.S. at 624.

105. Id. at 628 (quoting Federal Railroad Administration findings at 50 Fed. Reg. 31,526 (1985)).

106. See id. at 624; Von Raab, 489 U.S. at 672.

107. See Vernonia School Dist. $47 J$ v. Acton, 115 S. Ct. 2386 (1995). 
particular, enjoy only a diminished expectation of privacy. ${ }^{108}$ Because students are, in a multitude of ways, subject to the quasi-parental authority of the schools, and because student-athletes voluntarily forgo certain interests of privacy, the Court found that urine tests in the school context were less intrusive than they would be among "free adults."

Second, the Court examined the methods used to collect and analyze the urine samples and held that these procedures did not represent a "significant" invasion of constitutional rights. ${ }^{10}$ Notably, the Court did not find it necessary to characterize the intrusion as "minimal" (the term employed in Skinner ${ }^{111}$ ); rather, it used such labels as "relative unobtrusiveness." 12 Whether this change in terminology will prove significant in future cases remains to be seen.

On the other side of the balancing test, the Court emphasized the importance of the governinent's interest in ensuring drug-free schools and found the tests of athletes to be reasonably calculated to serve that interest. ${ }^{113}$ The Court further held that, in special needs cases, the proper inquiry is not whether the government interest involved is "coinpelling," as opposed to inerely "important" or "significant." Rather, the inquiry is whether the interest proffered "appears important enough to justify the particular search at hand."114 With this change, the Court seeined to remove even the thin verbal floor that Skinner and Von $R a a b$ had left intact, rendering the special needs balancing analysis even more standardless than before.

Finally, in response to the argument that suspicion-based drug testing would have addressed the government's interests adequately while intruding less deeply upon students' privacy interests, the Court emphasized that testing schemes need not be the "least intrusive" means available to reach the stated ends. ${ }^{115}$ The Court held that even if such a suspicion-based testing program were "practicable" in the school setting (and the Court offered several reasons why it may not have been), the school was not obligated to choose such a scheme over the suspicionless tests it did choose. ${ }^{116}$ This portion of the opinion left

108. See id. at 2391-93.

109. Id. at 2392.

110. Id. at 2393-94 (noting that students remain fully clothed while producing the sample and are subject to only unobtrusive observation, if any, that the tests do not screen for medical conditions other than drug use, and that the results are not used for any law enforcement or disciplinary purpose).

111. Skinner v. Railway Labor Executives' Ass'n, 489 U.S. 602, 624 (1989).

112. Vernonia, $115 \mathrm{~S}$. Ct. at 2396.

113. See id. at 2394-96.

114. Id. at 2394-95.

115. Id. at 2396.

116. See id. (noting that a requirement of suspicion would damage parental support for drug testing, risk arbitrary testing decisions, require schools to defend more lawsuits, and divert teachers from their central educational tasks). 
some uncertainty as to whether governmental actors seeking to impose suspicionless testing would still be required to show that requiring reasonable suspicion would be "impracticable"117 or would place the governmental interest served by the testing in "jeopardy."118

More recently, however, the Court has taken a small step back from the abyss of suspicionless drug testing. In Chandler $v$. Miller, ${ }^{119}$ the Court voted 8-1 to strike down a Georgia statute requiring candidates for certain state offices to submit negative drug test results in order to qualify for the ballot. ${ }^{120}$ Most importantly, the Court held that Georgia had not demonstrated a "special need" for the drug testing. ${ }^{121}$ After acknowledging that Skinner, Von Raab, and Vernonia provided the frainework for assessing the statute, ${ }^{122}$ the Court offered a crystallization of the special needs approach that was arguably much narrower than those offered in the earlier cases. "[T] he proffered special need for drug testing must be substantial-important enough to override the individual's acknowledged privacy interest, sufficiently vital to suppress the Fourth Amendment's normal requirement of individualized suspicion." 123

Next, the Court applied this narrow formulation of the special needs test. It noted first that Georgia did not contend that drug abuse was present among candidates for the covered state offices. ${ }^{124}$ Then, the Court held that the State had not demonstrated that suspicionless testing was necessary to detect any drng abuse that might exist among candidates. It found the statute to be poorly tailored to detecting casual users of drugs, and speculated that it offered no improvement over "ordinary law enforcement methods" in detecting any "addicted individuals" who might run for office. ${ }^{125}$

The Court distinguished the drug tests at issue in Chandler from those in Von Raab, which the Court had upheld despite the absence of evidence showing that there was any drug abuse problem among the Customs Service employees subject to testing. "Hardly a decision opening broad vistas for suspicionless searches," the Court wrote, "Von Raab must be read in its unique context." agents, unlike state elected officials, had primary responsibility for drug interdiction, and therefore were subject to unique pressures and

117. See New Jersey v. T.L.O., 469 U.S. 325, 351 (1985) (Blackmun, J., concurring).

118. See Skinner v. Railway Labor Executives' Ass'n, 489 U.S. 602, 623-24 (1989).

119. 117 S. Ct. 1295 (1997).

120. See id. at 1298-99 (describing Georgia statute at issue).

121. See id. at 1303.

122. See id.

123. Id.

124. See id.

125. Id. at 1304.

126. Id. 
temptations that drug abuse or addiction would exacerbate. ${ }^{127}$ Moreover, Customs Service employees worked in settings that rendered "dayto-day scrutiny" of their activities impossible. ${ }^{128}$ State candidates, "in contrast, are subject to relentless scrutiny - by their peers, the public, and the press." 129

Finally, the Court concluded that the Georgia statute could effectively serve only the "symbolic"130 need for the State to "display[] its commitment to the struggle against drug abuse."131 This purpose, the Court held, was not sufficient by itself to justify suspicionless drug tests. "However well-meant, the candidate drug test Georgia has devised diminishes personal privacy for a symbol's sake. The Fourth Amendment shields society against that state action."132

In a concluding paragraph, the Court stated that "where the risk to public safety is substantial and real, blanket suspicionless searches calibrated to the risk may rank as 'reasonable."'133 It cited routine searches at airports and court entrances as examples of presumably permissible suspicionless searches. ${ }^{134}$ The Georgia statute, then, failed scrutiny because "public safety [was] not genuinely in jeopardy."135

It remains to be seen how lower courts will respond to this latest Supreme Court decision. Judges generally hostile to suspicionless drug or HIV tests may see, in the stronger formulation of the special needs standard and the narrowing of Von Raab to its facts, an invitation to strike down testing schemes they would have felt constrained to uphold absent the Chandler decision. Judges who wish to uphold suspicionless testing programs, however, will have little difficulty finding a "risk to public safety" that is "substantial and real."136 Skinner, Von Raab, and Vernonia - all of which the Court reaffirmed in Chandler-cover a vast territory. A great many individuals remain subject to suspicionless drug and HIV testing on the basis of the special needs balancing analysis.

127. See id.

128. Id. (quoting National Treasury Employees Union v. Von Raab, 489 U.S 656, 674 (1989)).

129. Id.

130. Id. at 1305.

131. Id. at 1304.

132. Id. at 1305.

133. Id.

134. See id.

135. Id.

136. Id. 


\author{
II \\ Lower Court CASEs Since 1989
}

\title{
A. Employment Drug Testing
}

Given the discretionary, imprecise nature of the analysis adopted in Skinner and Von Raab, it is not surprising that the lower federal courts have reached varied, and sometimes conflicting, results in cases involving suspicionless drug tests of employees. ${ }^{137}$ Broadly speaking, two tendencies have emerged from these cases, both perfectly compatible with the Supreme Court's language in the 1989 cases and its decisions since then.

In one discernible line of cases, courts have interpreted Skinner and Von Raab expansively, analogizing freely from the railroad and Customs Service employees in those cases to approve testing of additional categories of workers. ${ }^{138}$ Courts in the other series of cases have applied Skinner and Von Raab more narrowly, seeking to distimguish the positions brought before them from those for which the Supreme Court upheld testing. ${ }^{139}$

All this is not to say that the lower courts have agreed on nothing. They have agreed, of course, that the analysis described in the 1989 cases governs Fourth Amendment challenges to suspicionless drug

137. In contrast, nearly all the cases that have addressed testing based on individualized suspicion have approved it. See, e.g., Dimeo v. Griffin, 721 F. Supp. 958, 972-73 (N.D. III. 1989), rev'd en banc on other grounds, 943 F.2d 679 (7th Cir. 1991); National Treasury Employees Union v. Watkins, 722 F. Supp. 766, 771 (D.D.C. 1989). For a case striking down some forms of suspicionbased drug testing for some categories of workers, see National Treasury Employees Union $v$. Yeutter, 918 F.2d 968 (D.C. Cir. 1990).

138. See, e.g., Dimeo, 943 F.2d at 685 (7th Cir. 1991) (jockeys, drivers, race starters, outriders, etc.); Yeutter, 918 F.2d at 971-72 (Agriculture Department motor vehicle operators); Bluestein v. Skinner, 908 F.2d 451 (9th Cir. 1990) (flight crews, flight attendants, air traffic controllers, maintenance personnel, etc.); Taylor v. O'Grady, 888 F.2d 1189 (7th Cir. 1989) (correctional officers in direct contact with prisoners); American Fed'n of Gov't Employees v. Skinner, 885 F.2d 884 (D.C. Cir. 1989) (motor vehicle operators, electronic technicians, aviation safety inspectors, railroad safety inspectors, etc.); Transport Workers' Union of Philadelphia $\mathrm{v}$. Southeastern $\mathrm{Pa}$. Transp. Auth., 884 F.2d 709 (3rd Cir. 1989) (operating enuployees of commuter railroad); Jones v. Jenkins, 878 F.2d 1476 (D.C. Cir. 1989) (school bus drivers); Enghsh v. Talladega County Bd. of Educ., 938 F. Supp. 775 (N.D. Ala. 1996) (mechanic's helper); Kenup v. Claiborne County Hosp., 763 F. Supp. 1362 (S.D. Miss. 1991) (surgical technicians); American Fed'n of Gov't Employees v. Cavazos, 721 F. Supp. 1361 (D.D.C. 1989) (Department of Education drivers), aff'd in part and vacated in part sub nom. American Fed'n of Gov't Employees v. Sanders, 926 F.2d 1215 (D.C. Cir. 1991); Brown v. City of Detroit, 715 F. Supp. 832 (E.D. Mich. 1989) (police officers).

139. See, e.g., Bolden v. Southeastern Pa. Transp. Auth., 953 F.2d 807 (3rd Cir. 1991) (en banc) (maintenance custodian for commuter railroad); Harmon v. Thomburgh, 878 F.2d 484 (D.C. Cir. 1989) (criminal prosecutors, Department of Justiee employees with access to grand jury proceedings); Beattie v. City of St. Petersburg Beach, 733 F. Supp. 1455 (M.D. Fla. 1990) (firefighters); American Postal Workers Union v. Frank, 725 F. Supp. 87 (D. Mass. 1989) (applicants for all positions at Boston post office); Watkins, 722 F. Supp. at 766 (motor vehicle operators, computer and communications specialists and assistants). 
testing programs. ${ }^{140}$ Moreover, they have agreed, either explicitly or implicitly, that Skinner and Von Raab together describe three general types of governmental interests that can, in the proper circumstances, justify suspicionless drug tests of employees. These interests are: maintaining the integrity of a workforce, ensuring public safety, and "protecting truly sensitive information." 141

Finally, though, the courts have disagreed more than they have agreed. Perhaps the most glaring difference of opinion took place within the United States District Court for the District of Columbia. In two cases decided in the same year, different judges in the District reached opposite results in addressing whether motor vehicle operators for cabinet departments could be tested for drugs without reasonable suspicion.

In National Treasury Employees Union v. Watkins, ${ }^{142}$ the court invalidated random testing of Department of Energy drivers. Despite the fact that some of the drivers carried guns in the course of their duties, the court refused to equate the positions with those of the gun-carrying customs employees in Von Raab. Unlike the latter, the Energy Department employees "[were] not law enforcement officers with ongoing contact with the public, engaged in the dangerous task of tracking criminals." ${ }^{\prime 43}$ The court found that the drivers' duties involved no greater risks than those "associated with vehicle use by the general public." 144

Approximately five weeks later, another judge in the same District upheld a testing scheme that included drivers for the Department of Education. ${ }^{145}$ Analogizing to the railroad employees in the Supreme Court's Skinner case, the court found that the drivers were "in a position where 'even a momentary lapse of attention' could result in harm." "146 The court believed this conclusion to be compelled by the D.C. Circuit's holding in Harmon v. Thornburgh, which the court interpreted as "stressing... the immediacy rather than magnitude of the

140. See e.g., Bluestein, 908 F.2d at 454 ; Harmon, 878 F.2d at 487.

141. Harmon, 878 F.2d at 488 (quoting National Treasury Employees Union v. Von Raab, 489 U.S. 656, 677 (1989)). Although Harmon struck down testing for most of the categories of employees involved, the court found itself compelled by Von Raab to uphold testing of workers with access to top secret information. See Harmon, 878 F.2d at 491-92.

142. 722 F. Supp. at 766.

143. Id. at 770 .

144. Id. at 769 .

145. See American Fed'n of Gov't Employees v. Cavazos, 721 F. Supp. 1361, 1361 (D.D.C. 1989). Subsequent panels of the District of Columbia Circuit also approved suspicionless testing of govemment motor vehicle operators. See National Treasury Employees Union v. Yeutter, 918 F.2d 968, 968 (D.C. Cir. 1990); American Fed'n of Gov't Employees v. Skinner, 885 F.2d 884, 884 (D.C. Cir. 1989).

146. Cavazos, 721 F. Supp. at 1373 (quoting Skinner v. Railway Labor Executives' Ass'n, 489 U.S. $602,628(1989))$. 
harm posed."147 The court thus construed Harmon as rendering the decision in Watkins (barely two weeks old at the time Harmon was decided) obsolete, ${ }^{148}$ even though Harmon itself struck down testing of criminal prosecutors and Department of Justice employees with access to grand jury proceedings. ${ }^{149}$

More generally, courts have disagreed over the importance of some of the factors weighed on either side of the balance of interests in Skinner and Von Raab. For example, in Beattie v. City of St. Petersburg Beach, a federal district court in Florida heavily discounted the governmental interest in testing because there was no evidence that drug use was taking place among the employees to be tested. ${ }^{150}$ While Von Raab had found such evidence unnecessary, ${ }^{151}$ the court in Beattie proceeded to hold that the remaining governmental interest in deterring drng use could not justify the suspicionless testing. ${ }^{152}$ In contrast, other courts have apparently read Von Raab more straightforwardly in this regard, either disregarding the lack of evidence of drng use in the workplaces involved ${ }^{153}$ or simply not discussing the question. ${ }^{154}$ The Supreme Court's recent decision in Chandler $v$. Miller ${ }^{155}$ may lend support to the narrower reading of Von Raab, but it is too soon to tell.

\section{B. Employment HIV Testing}

In contrast to the multitude of cases since 1989 involving drug testing of einployees, only a few have addressed HIV testing in the employment context. In one such case, the Fifth Circuit Court of Appeals upheld a government-run hospital's decision to fire a nurse for refusing to disclose the results of his HIV test. ${ }^{156}$ Although the court conducted its analysis using the suspicionless drug testing cases, ${ }^{157}$ it ultimately held that the case at hand was one of "particularized, reasonable suspicion as

147. Id. (citing Harmon v. Thomburgh, 878 F.2d 484, 491 (D.C. Cir. 1989)).

148. See id. at 1374 n.21.

149. See Harmon, 878 F.2d at 492.

150. See Beattie v. City of St. Petersburg Beach, 733 F. Supp. 1455, 1458 (M.D. Fla. 1990) (finding that "the City has no evidence of drug use among any of its fire fighters either on or off duty" and thus that the testing program was "directed solely at deterring future problems").

151. See National Treasury Employees Union v. Von Raab, 489 U.S. 656, 673-75 (1989).

152. See Beattie, 733 F. Supp. at 1458.

153. See, e.g., Taylor v. O'Grady, 888 F.2d 1189, 1194 (7th Cir. 1989) (quoting Von Raab's statement that "[t]he mere circumstance that all but a few of the employees tested are entirely innocent of wrongdoing does not impugn the program's validity," 489 U.S. at 674, then dropping the matter entirely); accord Harmon, 878 F.2d at 487-88.

154. See, e.g., American Fed'n of Gov't Employees v. Skinner, 885 F.2d 884 (D.C. Cir. 1989) (making no mention, in an opinion running fifteen pages, of whether any evidence revealed drug use among the covered employees).

155. 117 S. Ct. 1295 (1997); see supra text at notes 119-135.

156. See Leckelt v. Board of Comm'rs of Hosp. Dist. No. 1, 909 F.2d 820 (5th Cir. 1990).

157. See id. at 832-33. 
to a specific individual."158 The court noted that the nurse had been treated for a condition often associated with HIV infection and had lived with a man who died of AIDS, and that therefore the hospital had an individualized reason to demand that he disclose his test results. ${ }^{159}$ This decision, therefore, can tell us little about the law regarding generalized HIV testing in situations where no reason exists to believe the subjects are infected.

Another case, which was actually decided shortly before Skinner and Von Raab, did address suspicionless HIV testing in the employment context. In Glover v. Eastern Nebraska Community Office of Retardation, the Eighth Circuit Court of Appeals held unconstitutional HIV testing of employees of a state agency serving mentally retarded people. ${ }^{160}$ The court grounded its decision on the balancing analysis described in such cases as $O^{\prime}$ Connor $v$. Ortega ${ }^{161}$ concluding that the risk of transmitting HIV in the course of the covered workers' duties was "negligible" and so did not justify suspicionless testing. ${ }^{162}$

A 1991 case, by contrast, upheld mandatory HIV testing for firefighters and paramedics. ${ }^{163}$ The court held that a government agency that seeks to test its employees bears the burden of proving "that mandatory testing is necessary and that other precautions against the transmission and contraction of ADDS will not be effective."164 Because the covered firefighters and paramedics encountered "high risk of bodily injury, lacerations, exposure to bleeding victims, puncture wounds and the like," they constituted "a high-risk group for contracting and/or transmitting the HIV virus."165 Moreover, other "precautions ... such as gloves, masks and other protective clothing, may not be practical in [their work] setting." 166 The City, therefore, carried its burden, and the court upheld the testing program.

The results in Glover and Anonymous Fireman are certainly reconcilable: in the former the risk of HIV transmission was not great

158. Id. at 833 n.23.

159. See id. at 833. For this reason, one commentator has used Leckelt as a salutary example of a decision "limiting HIV testing to individuals who were subject to a reasonable risk of exposure." James E. DeLine, Note, Compulsory AIDS Testing of Individuals Who Assault Public Safety Officers: Protecting the Police or the Fourth Amendment?, 38 WAYNE L. REv. 461, 485 (1991).

160. 867 F.2d 461 (8th Cir. 1989).

161. See id. at 463 (citing O'Connor v. Ortega, 480 U.S. 709, 719 (1987)). For a discussion of $O^{\prime}$ Connor, see supra notes $80-85$ and accompanying text.

162. Glover, 867 F.2d at 464 .

163. See Anonymous Fireman v. City of Willoughby, 779 F. Supp. 402,417 (N.D. Ohio 1991). It is worth noting that, by combining the result in this case with that in Beattie v. City of St. Petersburg Beach, one reaches the conclusion that firefighters may be tested against their will for HIV, but not for illegal drugs. See supra notes 150-152 and accompanying text.

164. Anonymous Fireman, 779 F. Supp. at 417.

165. Id. at 412 .

166. Id. 
enough to justify testing, while in the latter it was. Yet the balancing formula is so protean that one suspects the difference in result rests inore upon each court's attitudes toward HIV and privacy than on any meaningful factual differences. Given the sorely limited guidance of Skinner and Von Raab, it is easy to imagine the courts in Glover and Anonymous Fireman reaching results exactly the opposite of their actual holdings. The inental health workers in Glover apparently worked with soine rather violent clients, who might have drawn blood from an employee at any moment. ${ }^{167}$ By the same token, a court might easily find that firefighters (leaving aside parainedics for the moinent) only rarely encounter situations in which they are exposed to other people's bodily fluids, or expose others to their own.

\section{Drug Testing of Accused Traffic Offenders}

Recently, two state high courts have upheld statutes requiring drug testing of individuals involved in certain injury-causing or fatal motor vehicle accidents. ${ }^{168}$ In one, a Maine statute mandated testing after any accident in which "a death has occurred or will occur," and allowed the results to be used in a criminal trial if the court found probable cause, independent of the test, to believe the driver was drugged or intoxicated. ${ }^{169}$ In the other, an Illinois statute instituted testing of drivers who were issued traffic tickets for non-equipinent-related offenses in connection with an accident that caused serious injury or death. ${ }^{170}$ The statute did not explicitly allow use of test results in criminal prosecutions, but it did not prohibit such use either. ${ }^{171}$

Maine's Supreme Judicial Court upheld the use of blood test results to obtain a driver's conviction for operating a vehicle under the influence of alcohol, believing that the United States Supreme Court's holding in Skinner effectively decided the constitutionality of the statute it confronted. ${ }^{172}$ It saw highways as a "highly regulated" 173 realm and gave great weight to "the public's interest in preventing highway fatalities resulting from drunk drivers." ${ }^{174}$ The court did not even consider the propriety of applying an analysis designed for "special needs,

167. See Glover v. Eastern Nebraska Community Office of Retardation, 867 F.2d 461, $462-63$ (8th Cir. 1989) (noting the state agency's concem over "clients who engage in violent or aggressive behavior associated with their conditions, such as biting and scratching").

168. See Fink v. Ryan, 673 N.E.2d 281 (Ill. 1996); State v. Roche, 681 A.2d 472 (Me. 1996).

169. Roche, 681 A.2d at 472 \& n.1 (citing ME. REv. STAT. ANN. tit. 29, § 1312(11)(D) (West 1993) (current version at ME REV. StaT. ANN. tit. 29-A, § 2411 (West 1996)).

170. See Fink, 673 N.E.2d at 283 (citing 625 Ill. CoMP. STAT. 5/11-501.6 (West 1994)).

171. See id. at 287-88; see also id. at 290 (Bilandic, J., dissenting) (pointing out that "search results will routinely be used in criminal proceedings").

172. See Roche, 681 A.2d at 473-75.

173. Id. at 474 .

174. Id. at 475 . 
beyond the normal need for law enforcement" to tests whose obvious purpose and effect was to obtain criminal convictions.

The Illinois Supreme Court also applied the special needs precedents in upholding the use of mandatory drug tests both to suspend impaired drivers' licenses and to prosecute them for driving under the influence of alcohol. ${ }^{175}$ The court found that "Illinois has a special need to suspend the licenses of chemically impaired drivers and to deter others from driving while chemically impaired."176 Balanced against that interest, the court found an individual privacy interest that was reduced by the highly regulated context of the state's highways and the reasonable expectation that a serious traffic accident will require the driver to remain at the scene to aid in the investigation (thereby making detention for drug or alcohol testing less intrusive). ${ }^{177}$ Finally, the court found that the use of the test results in criminal proceedings was "incidental" to the more central administrative purpose and that the United States Supreme Court's cases had not ruled out such criminal use of results. ${ }^{178}$

\section{HIV Testing of Accused and Convicted Prostitutes}

As of Spring 1997, no federal court case had addressed HIV testing of prostitutes. Only state courts in California and Illinois had done so, and both dealt only with tests of convicted (as distinct from accused) prostitutes. ${ }^{179}$ Each upheld the constitutionality of such testing, and numerous other states have passed statutes similar to those involved in the two reported cases. ${ }^{180}$

Moreover, even though no court has decided upon the constitutionality of tests of persons accused of prostitution, at least two states have passed statutes requiring such testing. ${ }^{181}$ While commentators speculate that testing of those merely accused of prostitution is uuconstitutional, ${ }^{182}$ it is not difficult to imagine courts approving snch tests out of deference to legislative decisions concerning pnblic health. ${ }^{183}$

175. See Fink, 673 N.E.2d at $284,287-88$.

176. Id. at 285 .

177. See id. at 286 .

178. See id. at 287.

179. See Love v. Superior Court, 276 Cal. Rptr. 660 (Ct. App. 1990); People v. Adams, 597 N.E.2d 574 (IIl. 1992).

180. See James G. Snell, Note, Mandatory HIV Testing and Prostitution: The World's Oldest Profession and the World's Newest Deadly Disease, 45 HAstings L.J. 1565, 1569 n.24 (1994) (listing statutes from fourteen states).

181. See Idaho Code § 39-604(3) (1997); OKIA. St at. tit. 63, \& 1-524(B) (1997); see also Snell, supra note 180 , at 1569 \& n. 27 .

182. See, e.g., Snell, supra note 180, at 1584-85 (stating that testing arrestees fails Fourth Amendment scrutiny because it "transfers the discretion [to test] to the authorities who actually make arrests," thus "allow[ing] for the possibility of abuse through selective arrests," and because the 
The cases upholding mandatory HIV testing of convicted prostitutes have followed a relatively straightforward special needs analysis. After characterizing the governmental interest in promoting public health and slowing the spread of ADS as compelling, ${ }^{184}$ these cases minimized the intrusion upon the prostitutes' privacy interests. ${ }^{185}$ The California case also dealt (albeit rather perfunctorily) with an additional wrinkle. Under the statute at issue, a person who tested positive for HIV and was subsequently convicted of prostitution again would be sentenced for a felony. ${ }^{186}$ This penalty enhancement feature raised the question of whether the search was truly designed to further government ends "beyond the normal need for law enforcement," 187 which is to say, whether or not it should have been analyzed under the frainework laid out in the special needs cases. The court dismissed this difficulty, saying that calling the tests a search for criminal evidence unfairly "ignore[d] the significant educational provisions of the [statute]."188 It read the testing and penalty enhancement as providing in combination "a means to deter acts known to spread [AIDS]" and therefore classified them as public health measures rather than criminal searches. ${ }^{189}$

Whereas the California court did not specifically find that convicted prostitutes possess a diminished expectation of privacy with regard to HIV tests, the Illinois court did. ${ }^{190}$ By virtue of their conviction, prostitutes "no longer enjoy[] a presumption of innocence but instead stand[] at the threshold of incarceration, probation, or other significant curtailment of persoual freedom."191 Both cases, however, upheld tests of convicted prostitutes on the theory that they served a vital governmental interest in safeguarding public health, without any real inquiry into whether the tests were truly necessary to serve that interest or whether other, less restrictive means were available.

\footnotetext{
presumption of innocence means "an arrestee has a greater expectation of privacy...than a convictee").

183. See Love, $276 \mathrm{Cal}$. Rptr. at 662 (noting the "large discretion" afforded the legislature in public health and stating that legislative determinations in this area are "conclusive on the courts" absent clear abuses or constitutional violations); accord Adams, 597 N.E.2d at 579.

184. See Love v. Superior Court, 276 Cal. Rptr. 660, 664-66 (Ct. App. 1990); Adams, 597 N.E.2d at 581.

185. See Love, 276 Cal. Rptr. at 664; People v. Adams, 597 N.E. 2d 574, 581-84 (Ill. 1992).

186. See Love, 276 Cal. Rptr. at 663 (citing CAL. Penal Code $\$ 1202.6$ (c) (West 1988)).

187. New Jersey v. T.L.O., 469 U.S. 325, 351 (1985) (Blackmun, J., concurriug).

188. Love, 276 Cal. Rptr. at 664.

189. Id.

190. See Adams, 597 N.E.2d at 583.

191. Id.
} 


\section{E. HIV Testing of Accused and Convicted Sex Offenders}

If courts are willing to uphold involuntary testing of convicted prostitutes, it is no surprise that they should do the same for tests of convicted sex offenders. In fact, at least one court has upheld involuntary testing for those merely accused of sex offenses. The first post1989 case dealing with a mandatory HIV test of an accused or convicted sex offender ${ }^{192}$ was Virgin Islands v. Roberts. ${ }^{193}$ In that case, the court ordered on its own authority an HIV test for a man merely accused, not convicted, of rape. ${ }^{194}$ Though it engaged in a balancing of interests, the court did not characterize the test as one justified by a special needs analysis. The court compared the government's interest in "protecting victims of sexual assault" and in "curbing the transmission of HIV" to the "minor" intrusion of testing and the limited disclosure of the results. ${ }^{195}$ Rather than asking whether this balance justified either a suspicionless test or one based on reasonable suspicion of HIV infection, the court allowed testing based on a magistrate's finding of probable cause that the defendant exposed the alleged victim to his semen. ${ }^{196}$

A number of states have passed statutes providing for mandatory HIV testing of persons accused or convicted of rape and other sexual crimes. ${ }^{197}$ In a 1993 case, In re Juveniles A,B,C,D,E, the Supreme Court of Washington upheld such a statute, at least insofar as it authorized testimg of juveniles who had been judged guilty of sex offenses. ${ }^{198}$ Unlike the Roberts court, the court in Juveniles relied squarely upon the special needs analysis. First, it declared that the purpose of the statute was not criminal. ${ }^{199}$ Next, it held that requiring individualized suspicion

192. At least one court has used the term "sex offender" in a way that includes prostitutes. See People v. Adams, 597 N.E.2d 574, 578 (IIl. 1992). I reject that usage as both uncommon and, for reasons that will become clearer as this Comment proceeds, unhelpful, and so 1 will use the term "sex offender" (or "accnsed sex offender") to refer to persons whose alleged crime is one of rape, child molestation, or some other act of sexual aggression or violation.

193. 756 F. Supp. 898 (D.V.I. 1991).

194. See id. at 900 (basing the court's power to order testing on FED. R. Crv. P. 41 and V.I. CODE tit. 5, §§ 3901-02 (1989)).

195. Id. at 901-04.

196. See id. at 901 .

197. See Bernadette Pratt Sadler, Comment, When Rape Victims' Rights Meet Privacy Rights: Mandatory HIV Testing, Striking the Fourth Amendment Balance, 67 WASH. L. REv. 195, 200 nn.4546 (1992) (listing some testing statutes for both accused and convicted rapists).

198. See In re Juveniles A,B,C,D,E, 847 P.2d 455 (Wash. 1993). Although the statute applied to persons "convicted" of sex offenses, and juveniles are said to be "adjudicated" to have committed the offenses, the court held that the legislature intended to include juvenile offenders in the testing program. See id. at 457.

199. See id. at 459 (noting that the statute is not part of the criminal code, is designed to protect public health and the health of both victim and offender, and does not seek evidence for criminal prosecutions). 
would be impractical, because HIV-positive persons generally show no outward signs of infection. ${ }^{200}$

Proceeding to the balancing portion of the test, the court found that blood tests generally present only a minimal intrusion upon the individual. ${ }^{201}$ Further, it found that convicted criminals (and sex offenders in particular) have a lesser right to privacy in their bodily fluids than other citizens, and thus that the intrusion of the tests was minimized even further. ${ }^{202}$ Finally, the court found that the limited disclosure provisions of the testing statute mitigated any "risk of stigmatic harm" associated with involuntary HIV testing. ${ }^{203}$

The court in Juveniles was careful to limit its holding to persons who had actually been found guilty of sex offenses. In answer to a dissenting justice's charge that the holding could justify testing of persons "not charged and convicted of criminal conduct," the court emphasized that the reduction in privacy expectations that results from conviction was a necessary part of its holding. ${ }^{204}$

Some later state statutes, passed after a federal law threatened the loss of victim support funds for states that did not act, mandate testing for persons accused of sexual assault only if the victim requests it. ${ }^{205}$ In evaluating such a statute under the special needs analysis, a Florida appellate court found in 1995 that "the State has a compelling interest in protecting and promoting public health and, here, in adopting measures reasonably designed to prevent the spread of AIDS."206 Having noted this governmental interest, the court stopped its analysis and upheld the statute without discussing the accused attacker's individual interests in avoiding the test.

The following year, an intermediate New Jersey court upheld a similar statute in a case involving testing of three juveniles who had been adjudicated delinquent of acts that would have, had the three been adults, amounted to aggravated sexual assault. ${ }^{207}$ Applying the special needs framework, the court found the state's interest in testing compelling. ${ }^{208}$ It then dismissed the defendants' argument that the stigma of a

200. See id.

201. See id. at 460 .

202. See id.

203. Id. (quoting Virgin Islands v. Roberts, 756 F.Supp. 898, 902 (D.V.I. 1991)).

204. Id. at 462.

205. See, e.g., Fosman v. State, 664 So.2d 1163, 1164 (Fla. Dist. Ct. App. 1995) (citing FlA. Stat. ANN. § 960.003 (West Supp. 1994)); State ex rel. J.G., 674 A.2d 625, 628 (N.J. Super. Ct. App. Div. 1996) (citing N.J. StaT. ANN. \$§ 2C:43-2.2, 2A:4A-43.1 (West 1994)).

206. Fosman, 664 So.2d at 1165-66 (quoting People v. Adams, 597 N.E.2d 574, 580-81 (Ill. 1992)).

207. See State ex rel. J.G., 674 A.2d at 626.

208. See id. at 631 . 
positive HIV test rendered the procedure more intrusive than other sorts of blood tests. ${ }^{209}$

Finally, the court addressed extensive testimony presented at trial to show that, due to the time it takes for an infected person to develop antibodies to the HIV virus, as well as other uncertainties, the tests the statute required were in fact "useless to the dominant intent of the legislation[,] which is to provide mformation to advance the diagnosis and treatment of the victim."210 In response, the court declined to give the trial court's finding of such "legislative' facts" preclusive effect, deferring instead to the state legislature's judgment that the tests would be of some use to the victims of sexual assaults. ${ }^{211}$

\section{F. HIV Testing of Persons Accused or Convicted of Assaulting Law Enforcement Officers}

Several states have passed statutes requiring or allowing involuntary HIV tests for individuals who may have passed bodily fluids to others, including public safety and health employees. ${ }^{212}$ This Comment will consider only those testing programs that affect persons who have been accused or convicted of assaulting law enforcement officers in such a way as to raise the question of whether HIV might have been transmitted. 213

As of Spring 1997, only one published opinion had considered such tests under the special needs analysis. ${ }^{214}$ In that case, the California

209. See id. at 632 .

210. Id; see also infra notes 242-245 and accompanying text (discussing the difficulties of using HIV tests of attackers to evaluate the health status of victims).

211. See State ex rel. J.G., 674 A.2d at 633.

212. See, e.g., ARK. CoDE ANN. § 20-15-905(b) (Michie 1995) (informed consent not required when health care provider or employee involved in bodily fluid contact "of a nature that may transmit HIV"); CaL. Health \& SAFETY CODE $\S 121060$ (West 1996) (involuntary testing of persons charged with interfering with police and other authorities by various fluid-transferring methods); Colo. Rev. Stat. ANN. § 25-4-1405(7.5)(a), (8)(a) (West 1996) (involuntary testing and release of results for persons whose bodily fiuids come in contact with public safety, health, and other employees); 410 ILl. CoMp. Stat. ANN. 305/7(b)-(c) (West 1996) (informed consent not required when health care worker or law enforcement officer comes in contact with person's bodily fluids); 1996 N.J. Sess. Law Serv. 115 \& 7(a) (West) (required testing if person charged likely to have transmitted HIV to officer, victim, or other person during commission of offense; involuntary testing at court's discretion if transmission not during course of offense); S.D. CoDIFIED LAws $\$ 23 A-35 B-6$ (Michie Supp. 1996) (law enforcement officer may request testing of defendant if reason to believe bodily fluids were transferred); WASH. REv. CODE ANN. § 70.24.340(4) (West 1997) (law enforcement officer, firefighter, or health care provider may request testing of person after exposure to bodily fiuids during course of employment).

213. For a discussion of additional statutes, see DeLine, supra note 159, at 473-79. DeLine argues that a given statute's constitutionality ought to turn on whether it applies only in situations where there is a "'medically siguificant' risk of transmission." Id. at 485.

214. See Johnetta J. v. San Francisco Mun. Court, 267 Cal. Rptr. 666 (Ct. App. 1990). Othcr courts have analyzed similar tests as criminal searches, Barlow v. Ground, 943 F.2d 1132, 1137-40 (9th Cir. 1991) (holding warrantless HIV test unconstitutional in absence of exigent circumstances or 
Court of Appeal upheld an HIV test of a woinan accused of biting a sheriff's deputy, despite its conclusion that the possibility of transmitting the virus in that manner was "extremely low" and merely "theoretical."215 The court found the state's interest in protecting its officers from even this remote risk of transmission sufficient to overcome the "minimal intrusion of a blood test." 216 In addition, the court noted that the persons to be tested would in most cases show no outward signs of HIV infection, so a requirement of probable cause or individualized suspicion would not be practical. ${ }^{217}$ Moreover, conflating accusation with gnilt, the court held that a person accused of assaulting a police officer had "voluntarily plac[ed] herself in a different category than $[\mathrm{an}]$ innocent or unsuspecting person."218 That is, her alleged actions had reduced her expectation of privacy in her own blood. Finally, the court found that the testing statute's disclosure provisions were sufficiently strict to minimize the potential stigmatic harm to the person tested. $^{219}$

\section{G. Lessons from the Lower Courts}

The single most striking message to be discerned from the special needs decisions since 1989 is that practically anything can happen. ${ }^{220}$ Because the special needs analysis grants such extensive discretion to the deciding court, each case becomes sui generis, bearing only as much similarity to those preceding it as the court chooses to see. The conflicting decisions on drng tests of government drivers are only the most apparent example. ${ }^{221}$

Upon reflection, it is certainly not surprising that the lower courts have reached such disparate results. The special needs analysis attempts to encapsulate vast factual differences within a single balancing formula. A range of persons from convicted rapists to data entry clerks must be situated on a virtually standardless scale to determine whether, and to what extent, their legitimate expectations of privacy have been "diminished." A complex equation involving both the importance of

other traditional warrant exception), or as searches supported by probable cause, Syring v. Tucker, 498 N.W.2d 370, 377 (Wis. 1993) (finding probable cause to test woman who bit social worker because the woman stated that she had AIDS).

215. Johnetta J., 267 Cal. Rptr. at 681.

216. Id.

217. See id.

218. Id. at 685 .

219. See id. at 680 .

220. See Nuger, supra note 20 , at 120 ("There is no objective methodology upon which to apply special needs criteria uniformly. Without a consistent methodology, its application will inevitably depend on how particular judges weigh the claims of the disputing parties.").

221. See supra text accompanying notes 142-149. 
the government's purposes and the efficacy of a given testing scheme must be characterized as "compelling" or "important," or neither.

Admittedly, some line-drawing will be necessary under any mode of analysis. Courts, after all, are in the business of applying rules of law to particular fact situations. It is far from inevitable, however, that the lower courts should be cast adrift so utterly as they have been by the special needs doctrine. A formulation is possible that preserves the ability of courts to take into account the particular facts before them and yet distinguishes more carefully among the general categories of cases that are likely to arise.

Another lesson that emerges from the cases is that the special needs analysis, susceptible though it is to the predilections of individual judges, produces a tendency toward upholding ever more intrusive testing regimes. ${ }^{222}$ The reason for this tendency is not difficult to discern: The analysis is cast in such a way that a large, sweeping public interest is opposed to the private sensitivities of a few employees (or, even worse, a few criminals). ${ }^{223}$ How many courts will be willing to say that railroad safety or the health of police officers is not a compelling interest? How many will stand in the way of such an interest simply to protect the bodily integrity of a small, often disfavored group of citizens? While a court might accept the importance of the interest and still find the tests overly intrusive, the test is in a sense "rigged" from the outset. 224

The lower court cases since 1989, then, teach us two contrasting yet compatible lessons. First, the special needs analysis provides inadequate standards for decision, leaving far too much to the discretion of the deciding court. Second, in its very structure and assumptions, the doctrine produces a tendency toward upholding even very intrusive drug and HIV testing schemes.

222. See Nuger, supra note 20 , at 129-31 (noting a trend toward upholding government tests and expanding the scope of the three special needs justifications outlined in Skinner and Von Raab).

223. See id. at 131 ("Individual privacy claims will inevitably lose this type of balancing test, for it is rare when individual behavior is pefceived as more important than the burdens forced on the public by the cumulative effect of the individual behavior."); $c f$. Thomas K. Clancy, The Role of Individualized Suspicion in Assessing the Reasonableness of Searches and Seizures, $25 \mathrm{U}$. MEM. L REv. 483, 630 (1995) ("The Court has often undervalued individual interests and overvalued governmental interests. It has reduced individual interests to a privacy analysis and has elevated mundane governmental interests to "special needs."')

224. A particularly obvious illustration of this tendency appears in Fosman v. State, 664 So.2d 1163 (Fla. Dist. Ct. App. 1995), in which the court's Fourth Amendment analysis did not evcn bother to assess the individual interests affected by mandatory HIV testing, instead simply noting the governmental interests at stake and then upholding the testing statute. See supra text accompanying notes 205-206. 
III

\section{A Critique of the Special Needs Balancing of Interests}

Most academic writing about the special needs doctrine has focused on one or another of the specific testing contexts outlined above in Part II. Writers have offered varying analyses of whether a particular kind of testing is constitutional under the special needs analysis. ${ }^{225}$ For the most part, however, they have not ventured to criticize the doctrine itself.

In one notable exception, Kenneth Nuger has argued that the special needs rationale should give way to an analysis utilizing "strict scrutiny and least intrusive analysis."226 By this he means that suspicionless tests should be allowed only where the government has demonstrated "that grave public harm would likely result in the absence of [the] proposed search and that the particular search scheme was the least restrictive possible scheme." 227

Nuger's reason for advocating such an analysis is that the current special needs framework tends to overemphasize the weight of governmental interests at the expense of individual rights. ${ }^{228}$ The analysis, he argues, is slanted toward approving very intrusive testing schemes that should not be allowed to stand. ${ }^{229}$ As an antidote to this tendency, strict scrutiny and least intrusive analysis would attach a far greater significance to the individual rights at stake and demand a more critical look at the claimed governmental interest. ${ }^{230}$ Because he deals almost exclusively with the employment drug testing context, however, Nuger is not prepared to offer a broader critique of the special needs rationale's scope. He simply accepts the doctrine's assumption that all suspicionless blood and urine tests should be analyzed under a single formula. ${ }^{231}$

None of these commentators, therefore, has criticized the special needs framework in its wide application to many different kinds of drug and HIV testing. This Comment, in contrast, argues that a primary failing of the special needs approach is that it throws together wildly

225. See, e.g., Barbara Danko, Comment, The Fourth Amendment's Challenge to Mandatory AIDS Testing of Convicted Sexual Offenders-Has the AIDS Virus Attacked Our Constitutional Right to Privacy?, 4 Seton HaLl ConST. L.J. 279 (I993); DeLine, supra note 159 (testing of people who assault public safety officers); Paul H. MacDonald, Note, AIDS, Rape, and the Fourth Amendment: Schemes for Mandatory AIDS Testing of Sex Offenders, 43 VAND. L. REv. 1607 (1990); Sadler, supra note 197 (testing of convicted and charged rapists); Snell, supra note 180 (testing of convicted and charged prostitutes).

226. Nuger, supra note 20 , at 131 .

227. Id. at 132 (citing Scott E. Sundby, A Return to Fourth Amendment Basics: Undoing the Mischief of Camara and Terry, 72 MiNN. L. REv. 383, 431 (1988)).

228. See id. at 129-31; supra notes 222-223 and accompanying text.

229. See Nuger, supra note 20 , at 129-31.

230. See id. at 131-34.

231. See id. at 136 ("IS]trict scrutiny should be the operative model to judge all Fourth Amendment challenges.") (emphasis added). 
disparate factual situations and attempts to resolve them using a generic balancing formula. It treats all of these situations as equivalent, and as equally amenable to its ad hoc weighing of governmental and individual interests.

In treating unlike cases alike, courts have more often than not erred on the side of allowing overly intrusive testing schemes to stand. Various courts' use of the analysis has revealed at least three different ways in which the special needs framework tends to skew the balance in favor of government testing schemes. First, as Nuger points out, the form of the analysis leads courts to overvalue the government interests at stake. ${ }^{232}$ Second, it encourages courts to give too much credit to governmeutal assessments of whether particular searches are necessary to serve the interests toward which they are aimed. Third, it leads courts to accept procedural regularity in the way searches are conducted as a substitute for more traditional forms of protection for the individual privacy interests that searches invade. Because Nuger does an adequate job of describing the first of these three shortcomings, this Part will concentrate on the latter two.

\section{A. The Facile Acceptance of Government Arguments Concerning Necessity}

The Supreme Court itself has been very willing to accept government lawyers' explanations for why a particular testing program is necessary to serve the purposes offered to justify it. The Court in Skinner, for instance, did not look past the government's assertion that basing drug and alcohol tests on individualized suspicion would be impractical. ${ }^{233}$ The responsible railroad supervisors had no training in spotting persons who might be under the influence of alcohol or drugs, and many users of those substances might exhibit no outward signs at all. ${ }^{234}$ Given these difficulties, how could a suspicion-based testing program be expected to work?

At the very least, this argument demands closer attention than the Court was willing to give it. Funds that might otherwise be spent on blanket testing programs might be used to train supervisors to spot workers under the influence of prohibited substances. Procedural safegnards, such as a requirement that two or even three supervisors concur before an individual could be referred for testing, would help to make

232. See id. at 129-31; supra notes 222-223 and accompanying text.

233. See Skinner v. Railway Labor Executives' Ass'n, 489 U.S. 602, 629 n.9 (1989) (declining to "second-guess" the government's conclusion that alternative approaches to drug problems were "wanting").

234. See id. at 628 ("An impaired employee... will seldom display any outward "signs detectable by the lay person or, in many cases, even the physician." (quoting Federal Railroad Administration findings at 50 Fed. Reg. 31,526 (1985)). 
such a scheme more reliable. In any event, habitual use of drugs-at least harder drugs-is probably not so difficult to detect as the Court would have us suppose.

In Vernonia, the Court accepted another official explanation for why tests based on individualized suspicion would not work. Such a testing program, the Court argued, would leave room for teachers or coaches to require tests based on their dislike or mistrust of specific students, without regard to whether those students actually showed objective signs of drug use. ${ }^{235}$ A blanket or random testing program, therefore, would actually protect students better than would a suspicionbased approach.

If applied across the spectrum of special needs drug cases, the latter argument proves far too much. Virtually all of the federal government's drug testing programs that have come before courts since 1989 have included provisions for testing based on individualized suspicion, in addition to the suspicionless tests that attracted more of the courts' attention. Those suspicion-based tests were either approved summarily ${ }^{236}$ or not addressed by the court at all. ${ }^{237}$ If testing based on supervisors' individualized suspicions of drug or alcohol use does not fall for fear of improper reprisals when it exists alongside suspicionless testing, there is no reason why it should do so when employed on its own.

Moreover, a supervisor or teacher who wishes to use an accusation of drug or alcohol abuse as a weapon against a subordinate or student could do so just as easily in the absence of a suspicion-based testing program as in its presence. Although being subjected to a blood or urine test is certainly an intrusion, that intrusion is not so awful that it would lead the hypothetical teacher with a grudge to make an accusation she otherwise would not make. The real damage of false accusation as a weapon is what it does to its object's reputation, and that damage is not significantly heightened by the fact that a suspicion-based testing program is the vehicle for the accusation. Instead, a suspicion-based testing program would provide the means for proving such allegations false.

235. See Vernonia School Dist. 47J v. Acton, 115 S. Ct. 2386, 2396 (1995) (arguing that suspicion-based testing "brings the risk that teachers will impose testing arbitrarily upon troublesome but not drug-likely students"). This concern seems odd in the context of a majority opinion that is fairly bursting with paeans to in loco parentis and the "custodial and tutelary" trust bestowed upon teachers and school authorities. Id. at 2392.

236. See National Treasury Employees Union v. Watkins, 722 F. Supp. 766, 771 (D.D.C. 1989) (upholding reasonable suspicion testing on the condition that it "shall be based on reasonable, articulable and individualized suspicion").

237. See Bluestein v. Skinner, 908 F.2d 451, 453 n.3 (9th Cir. 1990); American Fed'n of Gov't Employees v. Skinner, 885 F.2d 884, 886 n.1, 888 n.6 (D.C. Cir. 1989); Harmon v. Thornburgh, 878 F.2d 484, 486 n.1 (D.C. Cir. 1989). 
In some respects, some of the suspicionless testing programs the courts have approved might well be less effective than suspicion-based alteruatives at combating drug and alcohol abuse. In Von Raab, employees were to be tested upon hiring or transfer/promotion to a covered position. ${ }^{238}$ In effect, then, employees (and potential einployees) were able to determine in advance when they would be tested. Given such notice, most employees would likely be able to stop using drugs for long enough prior to the testing to render the result negative. ${ }^{239}$ Arguably, then, testing based upon suspicion might be more effective in detecting drug users than the policy the Court upheld. ${ }^{240}$

In the HIV context, several courts have accepted weak arguments as to why testing of one person is necessary to determine whether another person has become infected. In upholding testing of an accused rapist, for example, the court in Virgin Islands v. Roberts stated that "[ $t]$ he outcome of an accused rapist's HIV test, because it supplies a vital ingredient in formulating an efficacious program of monitoring and treatment for the victim, directly affects the physical and mental wellbeing" of the victim. ${ }^{241}$

A positive HIV test of the accused, however, even assuming his guilt, would not indicate that the victim had been infected with the virus. The most that the victim might learn from a test of the accused rapist is that she had in fact been exposed to the AIDS-causing virus. ${ }^{242}$ In order to determine in any conclusive fashion whether she had in fact been infected, she would have to undergo HIV testing herself periodically during the months following the attack. ${ }^{243}$

Similarly, a negative test result for the accused would not eliminate the possibility that he had transmitted HIV to the victim; he may simply not yet have begun exhibiting the antibodies for which HIV tests

238. See National Treasury Employees Union v. Von Raab, 489 U.S. 656, 660-61 (1989).

239. The Supreme Court recently employed this very argument in striking down tests of candidates for elective office. See Chandler v. Miller, 117 S. Ct. 1295, 1304 (1997) (noting that prior notice of testing meant that most "users of illegal drugs . . . could abstain for a pretest period sufficent to avoid detection").

240. The same could not be said of the policy in Skinner, which required testing after accidents and allowed it after safety rule violations. See Skinner v. Railway Labor Executives' Ass'n, 489 U.S. 602, 606 (1989).

241. Virgin Islands v. Roberts, 756 F. Supp. 898, 903 (D.V.I. 1991).

242. See Johnetta J. v. Municipal Court, 267 Cal. Rptr. 666, 670 (Ct. App. 1990) (upholding statute requiring testing of person who bit police officer despite very limited usefulness of results to victim's treatment or peace of mind).

243. See id. (citing expert testimony that " $[\mathrm{t}]$ he only way for a person actually or potentially exposed to HIV to know if he or she has been infected is to have him or hersclf tested for antibodies twice, once three months after the possible exposure and again six months after the possible exposure"). 
search. ${ }^{244}$ Again, the victim would still have to be tested herself in order to be certain about her own HIV status. Similar problems exist in the other HIV testing contexts reviewed in Part II. Although these problems do not necessarily render tests of a convicted (rather than an accused) rapist impermissible, courts under the current special needs framework have given too much credit to their effectiveness. ${ }^{245}$

The failure by the courts to apply a rigorous standard of review comes with heavy costs. The facile acceptance of government arguments for necessity strikes at the very heart of the Fourth Amendment's concerns. From a historical perspective, important governmental ends will always exist, and government will always seek stronger and stronger means by which to seek those ends. As Anthony Amsterdain wrote nearly a quarter-century ago, the Fourth Amendment serves to deny government "desired means, efficient means, and means that must inevitably appear from time to time throughout the course of centuries to be the absolutely necessary means, for government to obtain legitimate and laudable objectives."246 The great danger to Fourth Amendment liberties comes "in the face of plausible-sounding governmental claims of a need to deal with widely frightening and emotion-freighted threats to the good order of society. $" 247$

\section{B. The Substitution of Procedural Regularity for Protection from Searches}

The Supreme Court has decided that procedural protections within a testing program can, at least to some degree, substitute for the protections traditionally provided by probable cause and reasonable suspicion requirements. In Skinner, the Court invoked such procedures in two different ways, both directed squarely at excusing the warrantless, suspicionless drug and alcohol testing of railroad einployees. First, the Court held that "the standardized nature of the tests and the minimal discretion vested in those charged with administering the program" effectively took the place of a warrant requirement, leaving "virtually no

244. See id; see also Anonymous Fireman v. City of Willoughby, 779 F. Supp. 402,412 (N.D. Ohio 1991) ("Most individuals seroconvert [exhibit antibodies] within six to twelve weeks after exposure to the HIV virus, but seroconversion often does not occur until up to six months after an occupational exposure. In cases of sexual transmission of the HIV virus, seroconversion may take one to three years.").

245. One court has acknowledged the problem with usefulness but declined to substitute its judgment for that of the state legislature on this issue. See State ex rel. J.G., 674 A.2d 625, 633-34 (N.J. Super. Ct. App. Div. 1996); supra text accompanying notes 210-211. Although that stance may be grounded in a reasonable philosophy of judicial restraint, it serves in the special needs context only to undercut the discretion that is vital to a court's ability to strike down an invasive testing program.

246. Amsterdam, supra note 21, at 353.

247. Id. at 354. 
facts for a neutral magistrate to evaluate."248 Later, the Court used the fact that "the [urine] sample is ... collected in a medical environment," along with the fact that the prescribed method of collecting the sample did not require the most direct observation imaginable of the subject during urination, to downplay the intrusion of urine testing upon constitutionally protected interests. ${ }^{249}$

These attempts to substitute regularity and notice for protection of bodily integrity represent a fundamental non sequitur, rooted in a mistaken analogy between drug and HIV testing cases and cases involving administrative inspections of physical property. Courts start with the relatively innocuous principle that a rational, uniform policy of inspection supported by legitimate government interests can replace individualized suspicion in such searches as housing inspections. ${ }^{250}$ Then, in a startling leap, they apply the same logic to compelled intrusions into the body (blood tests) and into the privacy of an intrinsically intimate act (urine tests), intrusions designed to uncover evidence of an activity or status that carries with it such severe repercussions as employment sanctions and social stigma.

As a preliminary matter, the very notion of an administrative search of blood or urine is Kafkaesque. While a routine inspection of plumbing or wiring seems to most of us merely one of the necessary costs of living im a complex, modern society, the same is not true of blood or urine tests. Intuition tells us that the leap from administrative searches of property to drug and HIV tests is dangerous and wrong; we should trust our intuition and refuse to make the leap.

Moreover, equating drug and HIV tests with the other searches characterized as administrative ignores the severe consequences that can spring from the former. In extreme cases, courts have disregarded explicitly criminal consequences and purposes in analyzing searches as if they were merely administrative. A California statute, for instance, provided that a convicted prostitute who tested positive for HIV and then was convicted again for prostitution would be sentenced as if the crime

248. Skinner, 489 U.S. at 622 (1989).

249. Id. at 626; cf. Chandler v. Miller, 117 S. Ct. 1295, 1303 (1997) (noting that due to careful procedural protections in drug testing scheme, "if the 'special need' showing had been made, the State could not be faulted for excessive intrusion"). Lower courts have tended to follow the Supreme Court's lead. See, e.g., Taylor v. O'Grady, 888 F.2d 1189, 1199 (7th Cir. 1989) (noting that "the safeguards in the [testing] program are desigued to minimize any possible error and stigma for [corrections] officers who test positive"); $c f$. American Fed'n of Gov't Employees v. Skinner, 885 F.2d 884, 891 (D.C. Cir. 1989) (holding that proeedural differences from the program evaluated by the Supreme Court in Skinner v. Railway Labor Executives' Association did not render testing scheme unconstitutionally intrusive).

250. See Camara v. Mun. Court, 387 U.S. 523, 538-39 (1967). 
were a felony rather than a misdemeanor. ${ }^{251}$ Effectively, then, a positive blood test result would lead, with only one intervening step, to a greatly enhanced criminal penalty. Nevertheless, the court analyzed the tests using the special needs approach, accepting the penalty enhancement provision as part of a "prevention strategy."252

The Supreme Court itself has been unwilling to look past the pretextual nature of a nominally administrative search scheme. In New York v. Burger, the Court analyzed as administrative a program of inspections whose avowed purpose was to uncover junkyards that trafficked in stolen automobiles and parts. ${ }^{253}$ The Court attempted to distmguish the administrative purpose of "ensur[ing] that vehicle dismantlers are legitimate busmesspersons and that stolen vehicles and vehicle parts passing through automobile junkyards can be identified" from the penal purpose of evidence gathering. ${ }^{254}$ Such a distinction is upon reflection every bit as tortured and unconvincing as it seems at first glance to be, and yet the Court upheld it on the basis of the same sort of procedural regularity that justified the housing inspections in Camara v. Municipal Court. ${ }^{255}$

Although they may not incur the same sort of criminal consequences, individuals who test positive for drags in the employment context face possibly severe sanctions, including the loss of their livelihood. ${ }^{256}$ Persons testing positive for HIV suffer a crushing psychological blow in learning that they have a fatal disease ${ }^{257}$ and also are subject to social stigma and employment discrimination, among other "psychosocial" consequences. 258

Given the possibility of criminal and other serious consequences, the idea that procedural regularity can substitute for probable cause and reasonable suspicion requirements seems misguided. If notice to

251. See Love v. Superior Court, 276 Cal. Rptr. 660, 663 (Ct. App. 1990) (citing CAL. PENAL CODE $\S 1202.6(\mathrm{c})$ (West 1988)); supra notes 186-189 and accompanying text.

252. See Love, $276 \mathrm{Cal}$. Rptr. at 664 (citing United States Public Health Services, Guidelines for Counseling and Antibody Testing to Prevent HIV Infection and AIDS, in 36 MORBIDITY \& MORTALITY WKLY. REP. 509-15 (1987)). Even if a court does refuse to apply the special needs analysis to testing schemes with criminal law purposes, it can sometimes approve warrantless testing, without individualized suspicion, on the basis of a balancing analysis. See Rise v. Oregon, 59 F.3d 1556,1559 (9th Cir. 1995) ("Even in the law enforcement context, the State may interfere with an individual's Fourth Amendment interests with less than probable cause and without a warrant if the intrusion is only minimal and is justified by law enforcement purposes.").

253. See New York v. Burger, 482 U.S. 691, 712-16 (1987).

254. Id. at 714 .

255. 387 U.S. 523 (1967); see supra notes $35-41$ and accompanying text.

256. See, e.g., American Fed'n of Gov't Employees v. Skinner, 885 F.2d 884, 888 n.5 (D.C. Cir. 1989) (noting that the Department of Transportation's drug testing scheme provides for dismissal of employees who test positive more than once or who fail to comply with the plan's provisions).

257. See Doe v. Roe, 526 N.Y.S.2d 718, 722 (N.Y. Sup. Ct. 1988) (likening the receipt of a positive HIV test to a "death sentence").

258. Id. 
potential test subjects can excuse an intrusion upon bodily integrity, then the government could theoretically test anyone for drugs, HIV, or other information provided they announced ahead of time their intention to do so, along with the events or statuses that would trigger the testing. If using accepted medical procedures (or otherwise safeguarding the health of the person tested) will serve to justify invasive searches, then few barriers reinain to extensive government testing programs.

\section{The Need for a Different Approach}

Constitutional analysis of drug and HIV tests should not follow such a perilous path. What is required, instead, is an approach that focuses clearly and consistently upon the Fourth Ainendinent interests that a search invades. The magnitude of the governmental interests served, the efficacy of the search in advancing those interests, and the procedures by which the search is conducted are all properly viewed as secondary questions, pertinent only after a determination that a given individual has acted in a manner that might allow the governinent legitimately to imvade her interests. No longer should courts have effectively limitless discretion to trade off individual interests against government needs they view as compelling, or against procedural regularity in the implementation of testing programs.

In traditional Fourth Amendment cases, the requirement of probable cause served to ensure that an individual whose person (or house, papers, or effects) was to be searched had, at least probably, done something to "deserve" the search. ${ }^{259}$ Specifically, she was, at least probably, believed to be in possession of one or more items that were legitimately sought by law enforcement authorities. Even when Terry $v$. Ohio and subsequent cases allowed some limited searches on the basis of suspicions not amounting to probable cause, the Court demanded that the person searched have done something to suggest to a reasonable person that she might be engaged in a criminal act, and that she might be carrying a weapon. ${ }^{260}$

259. In using the word "done" here, I mean to include acts or conditions that are not necessarily volitional. Under traditional Fourth Amendment doctrine, a person's dwelling might be subjected to search even if the owner had no knowledge of or involvement in the presence of searched-for items within the dwelling. Still, the probable cause requirement demands specific, localized reason to believe that such items are present.

260. See Terry v. Ohio, 392 U.S. 1, 21-24 (I968). According to one commentator, probable cause and individualized suspicion

place[] the focus of the inquiry concerning the permissibility of a search or seizure upon the circumstances presented by the private party or object of the search or seizure; if and only if the individual or object provides a reason for governmental inquiry may the government intrude. Thus, the justification for the government's actions are [sie] not based upon circumstances within the control of the government.

Clancy, supra note 223 , at 485 . 
The special needs cases depart decisively from any such requirement. They demand neither reason to believe that the evidence sought is in fact present, nor any criminal or even suspicious action by the person searched that could legitimately lessen her Fourth Amendment protection and subject her to search. Courts have stated that persons subject themselves to tests merely by taking jobs, for instance. ${ }^{261}$ Taking a job, however, is not an action suggestive of any wrongdoing, much less a specific wrongdoing related to the evidence the test seeks to uncover.

All of this is to say that the special needs cases do not require (although a few of them do include) evidence of blameworthiness on the part of the person tested. This Comment contends that the concept of blameworthiness should be the starting point for analyzing the categories of involuntary drug and HIV tests discussed. Only categories of persons who have committed blameworthy acts should be subjected to involuntary blood or urine tests. Within those categories, courts will have to inquire further into the efficacy of the tests, the governmental interests they serve, and the procedures by which they are conducted, in order to determine if any particular testing program is justified. Outside those categories, however, no individual should have to submit to drug tests in the absence of (at least) individualized suspicion that she is using prohibited drugs, and no person should have to give in to unwanted HIV tests for any reason. The next Part lays out this blameworthiness approach in more detail.

\section{IV}

\section{AN INDIVIDUAL BLAMEWORTHINESS APPROACH TO DRUG AND HIV TESTING}

\section{A. Why Look at Blameworthiness?}

If the foregoing critique demonstrates anything about the special needs analysis, it is that it gives short shrift to the individual interests the Fourth Amendment is meant to protect. By overestimating governmental interests, accepting weak arguments for the efficacy of testing schemes in serving those interests, and substituting procedural regularity for protection from the intrusions occasioned by drug and HIV tests, the special needs framework allows courts discretion to uphold unacceptable intrusions upon the bodily integrity and privacy of individuals.

261. See, e.g., National Treasury Employees Union v. Von Raab, 489 U.S. 656 (1989); Skinner v. Railway Labor Executives' Ass'n, 489 U.S. 602, 627 (1989) ('[T]he expectations of privacy of covered employees are diminished by reason of their participation in an industry that is regulated pervasively to ensure safety ....."); American Fed'n of Gov't Employees v. Cavazos, 721 F. Supp. 1361 (D.D.C. 1989), aff'd in part and vacated in part sub nom. American Fed'n of Gov't Employees v. Sanders, 926 F.2d 1215 (D.C. Cir. 1991). 
These intrusions are unacceptable because they both require and advance a misguided conception of the Fourth Amendment as an instrument for the efficient execution of governmental purposes, rather than as a safeguard of individual liberties against governinent transgressions. In the special needs analysis, the governinent's administrative imperatives becoine the primary focus, and intrusions upon individuals are inerely currency to be bargained away in exchange for convenience or "necessity."

This view of the Fourth Annendment as primarily concerned with efficient administration of government purposes is certainly at odds with the political circumstances surrounding the Amendment's adoption. The men who pushed for the passage of the Bill of Rights were highly suspicious of centralized governinent power, a suspicion born naturally enough out of their recent experience under British colonial domination. ${ }^{262}$ Debates continue to this day about what specific practices the Framers may or may not have wished to proscribe. ${ }^{263}$ But surely they did not intend the Fourth Amendment to become a mere tool of administrative efficiency. They meant it to stand as a barrier to exercises of that very efficiency whenever it threatened to trample upon the individual liberty they had fought so hard to wim. ${ }^{264}$

Moreover, looking beyond speculations as to the Framers' intentions, textual and structural considerations support a reading of the Fourth Amendment as centrally concerned with individual liberty rather than administrative efficiency. The Amendment commands that " $[t]$ he right of the people to be secure... against unreasonable searches and seizures, shall not be violated." Only by the most extreme narrowing

262. See Amsterdam, supra note 21 , at 400 :

To be sure, the framers appreciated the need for a powerful central government. But they also feared what a powerful central government might bring, not only to the jeopardy of the states but to the terror of the individual ....

$\cdots$

... [T] he authors of the Bill of Rights had known oppressive government. 1 believe they meant to erect every safeguard against it. 1 believe they meant to guarantee to their survivors the right to live as free from every interference of government agents as our condition would permit.

263. See, e.g., Clancy, supra note 223, at 488-90; Tracey Maclin, Informants and the Fourth Amendment: A Reconsideration, 74 WASH. U. L.Q. 573, 579 (1996) (suggesting that the Framers intended "general searches and seizures [to be] illegal on their face"). For a general discussion of Framers' intent arguments in this context, see Morgan Cloud, Searching Through History; Searching for History, 63 U. CHI. L. REv. 1707 (1996) (review of unpublished dissertation).

264. The application of Fourth Amendment protections against the states, see Ker v. California, 374 U.S. 23 (1963) (applying Fourth Amendment exclusionary rule against states); Wolf v. Colorado, 338 U.S. 25, 27-28 (1949) (applying Fourth Amendment prohibition against unreasonable searches and seizures to states), likewise reflects the growing realization in the years surrounding the Civil War that the states were themselves potent threats to individual liberty. See Akhil Reed Amar, The Bill of Rights and the Fourteenth Amendment, 101 YALE LJ. 1193, 1217 (1992) ("For if the years leading up to the Revolutionary War had dramatized the special danger of central tyranny, .... the Civil War era demonstrated that states required constitutional restraints as well."). 
and contorting of the rather innocuous word "unreasonable" can the Amendinent be made into the servant of governmental efficiency. ${ }^{265}$

From a structural point of view, it has long been claimed that in our system of government the courts stand as guardians of individuals against the often imperious dictates of majorities and popularly elected officials. ${ }^{266}$ Their most potent weapon in that cause has been the Contitution, especially the Bill of Rights. ${ }^{267}$ The balance of the system, and the protection for minorities and individuals that it promises, cannot stand to have the Fourth Amendinent converted to an instrument for measuring governmental convenience.

None of the foregoing discussion means that concern for the functioning of government has no place at all in discussions of the Fourth Amendment. Indeed, the Amendment's own declaration that warrants may be issued upon a prescribed form of probable cause, ${ }^{263}$ and the implicit corollary that searches upon such warrants are usually permissible, reflects a judgment that government ends do sometimes require as their means searches of private "persons, houses, papers, and effects."269 But the "balancing" of Fourth Amendment interests against government purposes that occurs in the special needs analysis carries this idea too far. The exceptional case, in which utterly pressing governmental imperatives justify a careful, limited departure from the extreme of absolute privacy, has come to be the norm. The exception has truly swallowed the mle, and this Comment presents a suggested route for overturning that unfortunate inversion im one area of Fourth Amendment analysis.

The remedy, then, for the persistent, systematic short-changing of individual liberty interests within the special needs balancing test is to focus earlier and more squarely upon those interests. Fourth Amendment analysis must treat individual interests as primary, as

265. Cf. Clancy, supra note 223, at 604-05 (noting that Court's assessment of "reasonableness" had declined so that "the standard of need required to be shown [to justify suspicionless searches] was reduced to one of practicality").

266. See, e.g., Stephen Reinhardt, The Supreme Court as a Partially Political Institution, 17 HaRv. J.L. \& PUB. PoL'y 149, 151 (1994) (describing the Supreme Court's "obligation to protect minorities against the majority, and to protect the people from their govemment"); Patricia M. Wald, Life on the District of Columbia Circuit: Literally and Figuratively Halfway Between the Capitol and the White House, 72 MnN. L. REv. 1, 13 (1987) ("[The Framers] looked to the judiciary as the branch primarily entrusted with protecting the liberties of citizens from the excesses of the other two branches.") (citing The Federalist No. 78 (Alexander Hamilton)).

267. See Amsterdam, supra note 21, at 353:

The Bill of Rights in general and the fourth amendment in particular are profoundly antigovernment docaments. They deny ... to democratic government... desired means, efficient means, and means that must inevitably appear from time to time throughout the course of centuries to be the absolutely necessary means, for government to obtain legitimate and laudable objectives.

268. See U.S. ConsT. amend. IV.

269. Id. 
fundamentally important in a way that the special needs framework does not.

Given the language and history of the Fourth Amendment, the most obvious solution might be to revive the framework of probable cause and reasonable suspicion. In the drug testing context, this Comment has suggested that a requirement of individualized suspicion might not be nearly as meffectual as some courts claim. In the case of HIV, however, the notion of basiug tests on probable cause or reasonable suspicion is immediately and overpoweringly disturbing. In the traditional analysis, probable cause and reasonable suspicion refer to a likelihood that the evidence sought will be found $\mathrm{m}$ the place to be searched. ${ }^{270}$ Yet unlike drug use, being HIV-positive is not evidence of any crime or other wrongdoing. In many employment contexts, even alcohol use may be a violation of valid workplace rules. But having HIV is not and should never be such a violation. Mandatory testing of groups at high risk for HIV infection is a specter unpleasant enough to discredit the simple, straightforward varieties of probable cause and reasonable suspicion in this setting.

Given this failure, it is tempting to use probable cause or suspicion of something else to justify drug or HIV testing. When probable cause exists to believe that a person has committed rape, for instance, perhaps that probable cause is enough to support involuntary HIV testing. ${ }^{271}$ But this line of argument is already detached utterly from the meaning of probable cause. If authorities have probable cause to believe that an individual possesses a stolen jet airliuer, they are thereby empowered to search only in places where the missiug jet could possibly be located. In much the same way, probable cause that a person has committed a rape only justifies searches that will shed light on whether he actually did the crime. An HIV test has no bearing on that inquiry, and therefore justifyiug it on the basis of such unrelated probable cause simply does not follow.

If probable cause and reasonable suspicion are largely dead ends, then what alternatives are there that would properly elevate individual interests $\mathrm{m}$ evaluating the kinds of searches involved in this Comment? One possible approach suggests itself from our review of the existing special needs analysis. Special needs examines the position of the persons to be tested to determine whether their reasonable expectations of privacy have been dimiuished in some way. Perhaps, then, it is merely uecessary to perform that examination at an earlier stage,

270. See Illinois v. Gates, 462 U.S. 213, 238 (1983); supra note 27.

271. In Virgin Islands v. Roberts, 756 F. Supp. 898 (D.V.I. 1991), the court imposed involuntary HIV testing on a man accused of rape based on a magistrate's finding of probable cause that the defendant exposed the alleged victim to his semen. See id. at 901. 
elevating individual expectations of privacy to a threshold position in the overall analysis.

Simply adapting the existing expectation of privacy approach, however, would perpetuate at least two problems inherent in the current special needs analysis. First, it would allow courts the discretion to use such inherently neutral, blameless activities as taking a job im a particular industry or government agency as a grounds for assigning a diminished expectation of privacy. This freedom to use actions that are not blameworthy agamst people is disturbing. It offends deep-seated notions of desert to say that a person gives up her protection against intrusive bodily searches simply by taking a job.

Second, the expectation of privacy approach contains an inflationary aspect: a few invasions of privacy, if condoned, may reduce the reasonable expectations of entire groups of people, thereby paving the way for further invasions. If, for instance, employees in a limited class of government occupations are subjected to drug or HIV testing, then it may reduce the reasonable expectation of other classes of employees to be free from such tests. One need not argue that this inflation process has no stopping place in order to find it dangerous and disturbing. While it may be doubtful, therefore, that the process I describe would ever sanction anything as drastic as blanket testing of the entire working population, it seems clear that it can (and under the existing special needs framework does) work to contract the reasonable expectations of mdividuals to be free from involuntary blood and urine tests.

\section{B. Blameworthiness as a Threshold Question}

Given these dangers inherent in the expectation of privacy approach, this Comment proposes a measure that is much more explicitly moral: the measure of blameworthiness. Such a measure coincides with our fundamental notions of guilt, as reflected in our criminal justice system. The only way in which a person should be able to subject herself to involuntary testing - that is, diminish her reasonable expectation of privacy with regard to such testing-is by doing something that is wrong. This approach accomplishes something at least roughly analogous to the function that probable cause and reasonable suspicion played in traditional Fourth Amendment cases. ${ }^{272}$ That is, it requires intrusions upon protected interests to be tied closely to some blameworthy, or at least suspicious, action by the person to be searched. To whatever limited extent the traditional probable cause requirement might allow a person's property or effects to be searched without at least suspicion of blaineworthy action, ${ }^{273}$ it does not seem objectionable

272. See supra Part III.

273. See supra note 259. 
that protection from such bodily intrusions as blood and urine tests should be even greater. The idea is simply that the integrity of an individual's body, blood, and urine ought to be inviolable in the absence of some blameworthy action by that person.

By using blameworthiness in this way, this approach ensures that the focus of the Fourth Aunendment analysis remains squarely on the liberty interests of the persons subject to testing. It relegates concerns of governinental efficiency to a secondary status, yet avoids the shortcomings of the alternative, "diminished expectations" approach discussed above. In place of the immense and inplausible interpretive weight placed upon "reasonableness" in the special needs cases, the blameworthiness approach offers a bright line of protection for bodily integrity and personal medical information. There are costs to this solution, surely, which will be addressed shortly. ${ }^{274}$ For now, though, the point is that a blameworthiness analysis would protect individuals' Fourth Amendment interests far better than the present special needs approach can.

The most obvious objection that one might raise to the blameworthiness approach is that drug and HIV tests are not punishinents, and therefore that it is irrelevant whether the persons to be tested have done anything wrong. Drug and HIV tests, this objection might continue, are public health measures, like mandatory vaccinations or quarantines. Linking such tests to blameworthiness, on this view, might not only hamstring involuntary testing programs, but also paint HIV testing and drug treatment as sanctions for misbehavior, thereby reducing people's willingness to be tested voluntarily.

The response to this concern is that its underlying premise-that the kind of HIV and drug tests at issue in this Comment are not punishments-is largely an illusion. An individual who sincerely does not wish to undergo HIV testing can only view a compulsory test as punitive, particularly given the range of unpleasant ramifications associated with a positive result.275 Involuntary drug testing, as argued earlier, nearly always includes sanctions of one kind or another for those who test positive. ${ }^{276}$ The claim that these tests are not punitive is nothing but an exercise in academic wish-fulfillment, an attempt to create reality by

274. See infra notes 282-287 and accompanying text.

275. Persons testing positive for HIV suffer a crushing psychological blow in learning that they have the virus that causes a fatal disease. See Doe v. Roe, 526 N.Y.S.2d 718, 722 (N.Y. Sup. Ct. 1988) (likening the receipt of a positive HIV test to a "death sentence"). They also are subject to social stigma and employment discrimination, among other "psychosocial" consequences. Id.

276. Those who undergo involuntary drug tests face severe sanctions including the loss of their livelihood. See, e.g., National Treasury Employees Union v. Yeutter, 918 F.2d 968, 973 (D.C. Cir. 1990) (noting that Department of Agriculture testing program subjects employees who test positive to "the full range of disciplinary sanctions, including removal") (citation omitted). 
describing it as one desires it to be. For those actually subject to involuntary testing, the punitive aspect is apparent.

Another objection that might be raised to using blameworthiness as a trigger for possible testing is that it imposes involuntary drug or HIV tests on the basis of a status (blameworthiness) rather than actions. Because this Comment characterizes such involuntary tests as a form of punishinent, basing their imposition upon a person's status would be troubling.

On one level, it seems a curious use of language to characterize the kind of blameworthiness advanced here as a status. Blameworthiness, after all, springs directly froin actions; those actions, moreover, are violations of criminal laws. ${ }^{277}$ Particularly when proposed as an alternative to an analysis that routinely imposes suspicionless testing on the basis of an individual's status as a student, an employee in a particular field, or a suspect in a criminal case, the blameworthiness approach does not appear to rest inappropriately upon status.

Viewed another way, however, the criticism has inerit. If the actions giving rise to a person's blameworthy status bear no relation to the objects of the drug or HIV tests to be imposed, then the charge of statusbased testing is more compelling. Moreover, if such unrelated tests are allowed in this context, then the approach may inadvertently open ground for searches that would clearly be objectionable. For instance, a blameworthiness approach with no requirement of a connection between the blameworthy act and the object of the search might subject an individual who was once convicted of theft to warrantless, suspicionless drug or HIV tests. Such a prospect is undesirable. The danger would be rather easily averted, however, by requiring that the drug or HIV tests in a given case be reasonably aimed at preventing or addressing harms sprimging from the blameworthy actions that incur the possibility of testing in the first place. An involuntary HIV test of a convicted rapist, for example, might be aimed at providing the victim with medical information for her own peace of mimd, or to allow her to minimize the risk that she will convey the HIV virus to others. These purposes are closely tied to the blameworthy action of the rapist and serve to limit the range of searches to which he might be subject. The same convicted rapist could not, on this approach, be subjected to involuntary HIV testing for the sole purpose of safeguarding his own health, because such a justification has no connection to his blameworthy act of rape. ${ }^{278}$

277. See infra Part IV.C.

278. An obvious question that arises is whether testing would be permissible to help prevent the convicted rapist from spreading HIV while he is in prison for the rape conviction. Putting aside the wishful thought that prison officials ought to be able to prevent inmates from engaging in conduct (such as sexual intercourse or sexual assault) that would risk communicating the virus, the connection between the blameworthy act of rape and preventing the rapist from spreading HIV while in prison 
Again, the initial inquiry into blameworthiness is not intended to constitute the entirety of the analysis in drug and HIV testing cases. Rather, blameworthiness should act first as a threshold requirement for any further "balancing" of interests. If a class of people has not engaged in any conduct that is blameworthy, then its members should not be subjected to involuntary testing without individualized suspicion. If the group's members have done something blameworthy, and the proposed testing relates closely enough to the consequences of the blameworthy actions, then courts should proceed to evaluate the testing program by considering the governmental interests to be served by testing, the necessity of the testing program to those purposes, and the relative intrusiveness of the particular testing methods.

At this second, balancing stage, blameworthiness will play a role as well. Courts will have to determine whether a particular program of testing is sufficiently necessary to overcome the individual privacy interests of the blameworthy individuals who will be subject to it. The particular kind of blameworthy action that subjects the class of persons to testing will to some degree determine the level of necessity the government should be required to show. That is, persons who commit the most heinous sorts of crimes may be required to undergo drug or HIV testing upon a relatively slender showing of necessity to government purposes. Persons who have committed more minor-but still blameworthy-acts should be able to demand a stronger showing. The role of blameworthiness in balancing will be examined further in Sections $\mathrm{C}$ and $\mathrm{D}$ of this Part.

\section{A Method of Assessing Blameworthiness}

The next obvious questions include what to count as blameworthy and how, at the balancing stage, to ineasure differing levels or kinds of blameworthiness against one another. For instance, are only criminal acts to be held as blameworthy, or might soine legal acts also incur susceptibility to a violation of bodily integrity? It is important to reiterate here that the blameworthiness approach examines the actions that incur testing, not the actions or statuses that the blood or urine tests seek to discover. In the suspicionless special needs cases, by definition, individuals are tested because of what they have done or where they find themselves, not because there is any reason to believe that they are more likely than others to have drugs or HIV in their bodies.

For purposes of evaluating the categories of searches at issue in this Comment, the question whether some legal acts might count as

for that act seems close enough to allow the possibility of testing. Of course, any such tests would still be subject to a balancing analysis to determine whether they were sufficiently justified by governmental interests to allow the intrusion. See infra Part IV.D. 
blameworthy is merely academic. In each category, the persons to be tested have either been convicted of a criminal act (such as rape, prostitution, or biting a police officer) or have not been proven to have done anything even remotely blameworthy (as in the case of those merely accused of crimes, or those who have simply taken jobs or gone to school). One could imagine, however, legal actions that much of society might consider blameworthy, such as committing adultery. Examining the question in this abstract, hypothetical way, it seems preferable to choose a bright line rule treating only criminal acts as blameworthy. Directly or indirectly, it is necessarily the state that seeks to impose involuntary drug or HIV testing upon individuals. Criminal laws are the most apparent indication of what actions the state, as representative of the populace, views as worthy of blame. To attempt to include other actions not proscribed by criminal laws would lead courts into a standardless wasteland.

For much the same reason, it makes sense at the second, or balancing, stage of the inquiry to use the laws established by governments as at least an approximate ineasure of the varying degrees or levels of blameworthiness associated with various acts. If, for instance, relevant federal and state criminal laws uniformly (or nearly uniformly) treat rape as a inuch more serious offense than prostitution, that fact probably reflects a highly generalized societal judgment as to the relative severity of those two crimes.

There may, however, be instances in which the severity accorded in criminal laws to various offenses reflects momentary passions or darker, more abiding prejudices among the populace. The widely disparate penalties prescribed in inany jurisdictions for crimes involving crack cocaine, for which the vast majority of the people arrested are black, and those involving powder cocaine, for which more white people are arrested than black, is one example. ${ }^{279}$ This Comment is not the place to examine Madisonian questions about the tensions between majority rule and minority protection. Suffice it to say that courts ought to retain some measure of discretion in assessing blameworthiness to deal with

279. Under federal sentencing guidelines, a first-time crack dealer must receive the same prison sentence as a person who sells 100 times the amount of powdered cocaine. See United States v. Lawrence, 951 F.2d 751, 754-56 (7th Cir. 1991) (upholding 100 to 1 ratio against constitutional challenge and noting cases from other circuits reaching saine result); Mary Pat Flaherty \& Joan Biskupic, Rules Often Impose Toughest Penalties on Poor, Minorities; Justice Dept. Says the System Is Free of Bias, WASH. Post, Oct. 9, 1996, at A1. According to a report by the United States Sentencing Commission, $88 \%$ of people convicted in federal court of crack-related crimes in 1993 were black, while only $27 \%$ of those convicted of powdered cocaine-related offenses were black, compared to $32 \%$ white and $39 \%$ Hispanic. See Gary Marx, Race Is at Center of Crack-Sentencing Debate, CHI. TriB., Oct. 30, 1995, at 1. Notably, a Sentencing Commission study called the severe penalties for crack cocaine dealing "clearly out of step with public opinion." Flaherty \& Biskupic, supra, at A26. 
quandaries such as this one. If a court decided to treat possession of either kind of cocaine as a siugle type or category of crime for purposes of the blameworthiness analysis, that would be entirely consistent with the spirit of this approach.

\section{Blameworthiness and Various Drug and HIV Testing Situations}

The approach advocated in this Comment defines categories of cases prior to adjudication, rather than conducting a separate balancing inquiry in each individual case. It examines for each testing program the blaneworthiness of the action or status that would trigger drug or HIV tests. If that action or status is not blameworthy, then this approach concludes that involuntary, suspicionless testing is unconstitutional. Persons merely accused of crimes, whether sex offenses, assaults on police officers, or prostitution, cannot be considered to have done anything blameworthy. The presumption of innocence means that such people cannot be tested on the ground that their own blameworthy acts have exposed them to invasions of their constitutional interests. ${ }^{280}$ Persons subjected to tests inerely because of their status as einployees in a particular industry or agency, or as students in an athletic program, are clearly free of blameworthiness. Neither our criminal laws nor our institutions assign blame to those statuses, and so those categories of people have not forfeited their protection against intrusive bodily searches.

Because they have done nothing blameworthy, these latter categories of persons should not be subjected to involuntary, suspicionless drug or HIV testing. ${ }^{281}$ Under the proposed approach, the absence of blameworthiness shields them from such testing no matter how compelling the governmental interests at stake, no inatter how well testing might serve those interests, and no matter how carefully the testing scheme is designed to provide procedural regularity or a medical environment for testing. Such persons might still be required to undergo involuntary tests for the presence of drugs that are illegal (or otherwise prohibited in a work, school, or jail setting) on the basis of probable cause or reasonable, individualized suspicion. Again, these conclusions rest upon the premise that the Fourth Amendment's central function ought to be to

280. In fact, one illustration of the special needs analysis' tendency to minimize the importance of individual freedoms is that it encourages courts to elide questions regarding the presumption of innocence. In Virgin Islands v. Roberts, 756 F. Supp. 898, 901 (D.V.1. 1991), the court based its decision to uphold testing of an accused rapist in part upon a magistrate's finding, at a pretrial hearing, of probable cause to believe the defendant had committed the crime. If mere probable cause is enough to overcome the protection that the presumption of innocence affords, then the analysis is deeply flawed indecd.

281. Although suspicionless, blanket drug testing of accused criminals has not been a topic of this Comment, it probably will produce litigation in the near future. The Clinton administration in 1995 adopted a policy of testing all individuals arrested on federal charges. See Alison Mitchell, Clinton Orders Drug Tests for Suspects in Federal Cases, N.Y. TImes, Dec. 19, 1995, at A15. 
safeguard individual liberty interests against intrusions made in the name of governmental efficiency. 282

It is important to acknowledge the implications of the proposed analysis. Even such employees as airline pilots, whose mistakes (whether drug- or alcohol-induced or not) could easily jeopardize the safety of a great many people, would not be subject to suspicionless testing under the blameworthiness analysis. While keeping airline pilots alert and capable during their working hours is vitally important, violating the sincere objections that some pilots might have to suspicionless testing is too high a price to pay for a speculative, highly uncertain payoff in increased safety.

If proponents of involuntary testing could show conclusively that their solution would save more lives than a combination of voluntary testing, treatment and education programs, supervisor trainimg, and suspicion-based testing, then my approach would be pushed to its extreme. Even if this were the case, I would still insist that any individual pilot who chose not to undergo testing could not be compelled to do so in the absence of reasonable suspicion that she herself was flying while impaired. When the government's administrative imperatives clash with core Fourth Amendment interests in this way, I would resolve the conflict in favor of individual liberty. Given that the safety benefits of involuntary suspicionless testing over the less intrusive measures mentioned above are far from clear, however, the case is easier to resolve. Even if serving the governmental purpose of airline safety could trump individual liberty concerns, that purpose may well not require the intrusion of mandatory testing.

Suspicionless HIV testing on the basis of employment would also be impermissible under the proposed analysis. Additionally, however, suspicion-based testing probably has no place here analogous to its role in drug testing. Unlike drug use, being HIV-positive is not illegal. Moreover, unlike drug use and on-the-job alcohol use, employers cannot make HIV-positive status a violation of any company policy. ${ }^{283} \mathrm{~A}$ "suspicion" that an enployee might be HIV-positive, therefore, is fundamentally different from a suspicion that an employee is working under the influence of drugs or alcohol.

Moreover, what would count as a "suspicion" of HIV infection? Admitted homosexual behavior? Suspected homosexual behavior? Promiscuous heterosexual behavior? Having a roommate who was

282. See supra notes 246-247, 262-269 and accompanying text.

283. Such a policy would seem indisputably to violate anti-discrimination laws. Cf., e.g., Raytheon Co. v. California Fair Employment and Hous. Comm'n, 261 Cal. Rptr. 197, 203 (Ct. App. 1989) (holding that AIDS is a physical handicap for purposes of state anti-discrimination law); Doe v. Denny's, lnc., 931 P.2d 816, 818 (Or. Ct. App. 1997) (en banc) (noting that HIV-positive status constitutes a physical impairment for purposes of state employment discrimination statute). 
treated for AIDS, as one court held? ${ }^{284}$ Or would only visible symptoms of AIDS-related illnesses count as suspicion? The first four options are clearly recipes for discriminatory treatment of gay men and others, while the last occurs so late in the progress of the virus that it could add little or nothing to a program of counseling and across-the-board measures designed to prevent the spread of HIV in a given employment context.

Just as airline pilots present the limiting case for drug testing, medical personnel present the hardest questions for HIV testing. Not surprisingly, some patients wish to know that the individuals responsible for their health care are not infected with HIV. Particularly in contexts such as surgery and einergency care, where medical personnel come into close contact with patients' open wounds, the concern over the HIV status of health care workers becoines inost understandable.

On the other side of the question, medical opinion seems to be predominantly agamst the necessity of testing health care workers. ${ }^{285}$

284. See Leckelt v. Board of Comm'rs of Hosp. Dist. No. 1, 909 F.2d 820, 822 (5th Cir. 1990).

285. See, e.g., Jeff Morris, HIV and the Health Care Profession: The Pitfalls in Creating a Comprehensive AIDS Policy, 2 KAN. J.L. \& PUB. PoL'y 99 (1992) ("Physicians, nurses, and mcdical associations ... oppose mandatory HIV testing and disclosure requirements."); Linda Gillis, AIDS Testing Limits Stressed: Hospital Official Sees No Effective Method, IndinNapolis News, July 12 , 1991, at E1 (quoting Dr. Marviu Berman, an adviser for the American Dental Association and chief of pediatric dentistry at Humana-Michael Reese Hospital in Chicago as saying mandatory testing of health care workers "wouldn't mean a darn thing," because "[w]e don't have an effective way of doing it"); Betsy A. Lehman, AIDS Tests for Health Caregivers?, Boston GLOBE, Aug. 10, 1992, at 27 (reporting that National Commission on AIDS "denounced mandatory AIDS testing of health care workers"); Michael Unger, Testing Debate Grows in a 'Policy Vacuum,' NEwSDAY, July 15, 1991, at 3, 20 (reporting that "[m]ost of the medical community opposes" mandatory testing); Union Opposes Mandatory AIDS Testing of Health Care Workers, U.S. Newswire, Sept. 26, 1991, available in 1991 WL 5149818 (reporting opposition to mandatory testing by American Federation of Stafe, County and Municipal Employees, "the nation's largest union for hcalth care workers").

For additional legal opinion opposed to mandatory HIV testing of health care workers, see, e.g., Pat Litchy, Mandatory HIV Testing of Health Care Professionals, 13 HAML.INE J. PUB. L. \& PoL'Y 347, 347 (1992) ("Mandatory HIV testing of health care professionals is ineffective in halting the spread of AIDS, a costly waste of health care dollars, and violates important individual rights. Further, mandatory HIV testing programs do not address any significant danger of transmission of AIDS, but rather are a political response to unfounded public fear."); Christine Huebner, Note, Mandatory Testing of Health-Care Workers for AIDS: When Positive Results Lead to Negative Consequences, 37 N.Y.L. ScH. L. REv. 339, 341 (1992) ("[A]Ithough the possibility of contracting HIV from a health-care worker is a serious consideration, the government must not succumb to the hysteria surrounding this issue by recommending mandatory testing of all health-care workers.").

Countervailing views are not, of course, entirely absent. See, e.g., Jane H. Barney, Comment, A Health Care Worker's Duty to Undergo Routine Testing for HIV/AIDS and to Disclose Positive Results to Patients, 52 LA. L. Rev. 933 (1992) (calling for recognition of a tort-based duty for health care workers to undergo HIV testing); Susie Stechkner \& Carolyn Poirot, AIDS Deaths Refuel Debate over Testing, FT. WORTh StaR-Telegram, June 9, 1991, at 1 (citing view of Dr. Sanford Kuvin, vice chairman of board of trustees of National Foundation for Infectious Diseases that "we need mandatory testing based on the premise that voluutary testing has failed"); Unger, supra (noting that "the prestigious New England Joumal of Medicine [has] called for routine HIV testing of doctors and other health professionals, as well as patients, pregnant womeu and newborns"). 
Preventive protocols are standard for all procedures that bear a significant risk of HIV transmission. ${ }^{286}$ These protocols, combined with strong programs of education, counseling, and voluntary testing, minimize the risk of contracting HIV from a health care worker. ${ }^{287}$

Despite these assurances from the medical profession, the fear of AIDS might possibly prevent some people from seeking medical care, thus harming the goals of public health. Subjecting health care workers to involuntary blood tests, however, is simply too strong a solution to a problem founded upon public ignorance. Government should work to disseminate the truth about the exceedingly low risk of contracting HIV in this manner, rather than appeasing public discomfort by intruding on health care workers' Fourth Amendment interests.

If the action or status that incurs testing passes the threshold of blameworthiness, then the inquiry proceeds to determine whether the program's combination of service to governmental interests and procedural protections can justify testing of persons who have engaged in a particular kind of blameworthy action.

The proposed analysis, therefore, treats one factor of the existing special needs analysis-the intrusion upon protected interests-as prior to, as well as part of, the case-by-case balancing analysis. The product of this change would be that some categories of tests would be impossible to justify, regardless of the governmental interests served or the procedural protections employed. Courts would have no discretion to use these latter factors to overcome the absence of blameworthiness. Other categories, meanwhile, would fall upon a continuum ranging from strong governmental interests and stringent procedures to relatively low governmental interests and simple procedural guarantees.

In 1991 the United States Centers for Disease Control (CDC) issued guidelines "calling on all workers who perform 'exposure-prone' procedures, presumably including surgery, to be tested for AIDS." Lehman, supra. However, "[T] he CDC stopped short . . . of recommending mandatory HIV testing." Duane Bidwell, U.S. Calls for Voluntary HIV Tests for Many Health Workers, Fr. WorTH StaR-Telegram, July 16, I991, at 1 .

286. States are required to adopt Center for Disease Control (CDC) guidelines and recommendations calling for "strict adherence to universal precautions" in the health care context. Jeffery W. Cavender, AIDS in the Health Care Setting: The Congressional Response to the Kimberly Bergalis Case, 26 GA. L. Rev. 539, 554 (1992).

287. See Symposium, Job Restrictions and Disclosure Requirements for HIV-Infected Health Care Professionals: Whose Privacy Is It Anyway?, 41 N.Y. L. Sch. L. REv. 5, 13-14 (1996) (noting that since several cases surrounding a single dentist in 1990, "there has not been a confirmed case of any other infected health care worker transmitting HIV to a patient while performing a medical procedure"); see also Cavender, supra note 286, at 546 (reporting only five cases of HIV transmission from a health care worker to a patient as of 1992). Health care workers themselves are apparently at a somewhat greater risk of contracting HIV through their work; one article reports that as of 1992, 44 out of 7250 infected health care workers had contracted the virus through needle sticks and other work-related avenues. See id. at 545 n.34. 
Among the categories of persons subjected to drug and HIV tests in the various cases, convicted sex offenders are certainly the most blameworthy, followed at a considerable distance by individuals convicted of assaulting police officers. Besides being supported by the societal judgments reflected in criminal laws, ${ }^{288}$ this ranking comports well with intuitive assessments of blameworthiness. Rape and other sexual assaults are horrid violations of other human beings' physical and psychological well-being. Assaulting police officers, while surely reprehensible and dangerous, simply does not seem as intuitively horrible as rape or child molestation, for instance. ${ }^{289}$

Prostitution, finally, while it is an act that most states' criminal laws consider blameworthy, has no victims, or at least no innocent victims. ${ }^{290}$ Moreover, prostitution may be for many women the only available option in the face of poverty, homelessness, and sexual abuse. ${ }^{291}$ In this sense, one might say that prostitutes themselves are the victims of prostitution. In any event, the exigencies of poverty and abuse, as well as the fact that the other participant (for whose benefit HIV tests would presumably be conducted) consents to the prostitution transaction, surely serve to reduce the level of blameworthiness of individuals involved in prostitution. The same claim cannot be made for violent sex offenders or for people who use violence against police officers.

Throughout this analysis, I have drawn the line between blameworthiness and non-blameworthiness at the point of criminal conviction.

288. See, e.g., CAL. PENAL CoDE $\S \S 264,264.1$ (West 1996) (assigning sentences of three, six, or eight years imprisonment for rape, and sentences of five, seven, or nine years for rape with certain aggravating circumstances); id. § 243(c) (assigning sentence of 16 months, 2 years, or 3 years for injury-producing battery upon a range of public officials including police officers); id. § 647 (treating prostitution as a misdemeanor and assigning 45-day jail sentence for second offense, and 90-day sentence for third offense); N.Y. PENAL LAW $\$ \S 70.00,70.02$ (McKinney 1996) (assigning sentences of 6 to 25 years imprisonment for first degree rape, up to 15 years for aggravated second degree sexual abuse, and up to seven years for aggravated third degree sexual abuse); $i d$. $\$ 70.02$ (assigning 6 to 25 years for aggravated assault on a police officer); id. $\S \S 55.05,70.15,230.00$ (assigning fine up to $\$ 500$ and jail term up to three months for prostitution).

289. While I believe these intuitive assessments to be widely shared in the United States today, I recognize that the mention of intuition invites disagreement over the way I have ranked actions for blameworthiness. For the most part, this Comment accepts the ordering of blameworthy actions reflected in criminal statutes. But see supra note 279 and accompanying text.

290. One case does speak of patrons or "johns" as the "victims of [prostitutes'] conduct." People v. Adams, 597 N.E.2d 574, 581 (IIl. 1992). Clearly, however, a person who patronizes a prostitute is not a victim in the same sense as is a person who is raped or otherwise sexually assaulted. Moreover, unlike victims of these other crimes, the "victims" of prostitution are themselves, by definition, gnilty of crimes. See id. at 576 (noting that "patronizing a prostitute" is an offense under the Illinois Penal Code).

291. See Andrea Dworkin, Prostitution and Male Supremacy, 1 Mich. J. Gender \& L. 1, 4-5 (1993); see also Tracy M. Clements, Prostitution and the American Health Care System: Denying Access to a Group of Women in Need, 11 Berkeley WoMEN's LJ. 49, 56 (1996) (describing the "radical feminist approach" to prostitution and citing sources on coercion and economic compulsions toward prostitution). 
From the point of view of the victim of a sex offense, it may seem harsh and unfair to forestall any possible mandatory HIV testing until after the alleged offender has been convicted. In many jurisdictions the criminal justice system proceeds slowly, and months or years may pass before the accused attacker's trial is completed. The victim, under the proposed analysis, must wait all the while without the benefit of whatever information and peace of mind the alleged attacker's test result might afford her. By the time the trial is over, in fact, that information might be of little or no value to her, becanse her own test results will more than likely be definitive as to her HIV status. ${ }^{292}$

Frankly, this implication of the analysis is disturbing. It seems preferable, however, to a framework that allows individuals entitled to the presumption of innocence to be tested against their will. The fundamental premise of this Comment is that the government should not be able to invade people's privacy interests unless those people have done something to incur such an intrusion. That premise would be incalculably weaker if in this one instance the government could test people on the ground that they may have done soinething.

The view that persons merely accused of sex offenses should not be subjected to involuntary testing might also seem excessive in light of the fact that such individuals might well be required to submit blood samples to be used as evidence in their criminal trials. If such a sample can be required for purposes of DNA testing, then perhaps there is no further harm in testing that blood for HIV as well, and then informing the victim of the results. In the drug testing context, however, the Supreme Court has held that, after a blood sample has been drawn, "chemical analysis of the sample to obtain physiological data" constitutes an additional "invasion of ... privacy interests." obtained for DNA testing purposes, therefore, is a new and separate invasion of Fourth Ainendment interests.

That conclusion, moreover, is especially true in the context of HIV testing. As noted above, a positive test result for the HIV virus carries with it serious psychological and social consequences. ${ }^{294}$ Such testing should not simply be swept up within an unrelated decision to allow DNA testing to help determine guilt or innocence.

It would be dangerous to suggest that blood samples obtained on the basis of a warrant designed to investigate the crime could be used without further justification for another test whose utility is dependent

292. On the delay before HIV can be detected by conventional tests, see supra note 244 and accompanying text; see also supra notes 242-245 and accompanying text (arguing that the attacker's test results are of little use to the victim even if obtained promptly).

293. Skinner v. Railway Labor Executives' Ass'n, 489 U.S. 602, 616 (1989).

294. See supra note 275 and accompanying text. 
on the assumption that the defendant has in fact committed the crime..$^{295}$ A warrant for DNA testing is issued precisely because the determination whether the defendant is guilty of the crime charged has yet to be made. A magistrate or other fact finder has, it is true, found probable cause to believe that the defendant is guilty. Still, DNA testing might as easily exonerate the defendant (and inform police that they need to continue seeking the true perpetrator) as support his guilt. HIV testing, on the other hand, can only genuinely contribute to the victim's peace of mind if the defendant is in fact guilty. Testing of a defendant who turns out not to have committed the crime might even lead the victim to make misguided treatment and lifestyle decisions. HIV testing, then, cannot proceed on the theory that the defendant's blood may be subject to seizure for DNA testing anyway, and therefore that no additional intrusion would be involved.

A final argument against requiring a conviction before subjecting individuals to suspicionless testing turns on the reduced Fourth Amendment protections afforded to pretrial detainees in the jail or prison setting. ${ }^{296}$ Because persons accused of prostitution or sex offenses are subject to pretrial detention, and because pretrial detainees are subject to greater intrusions upon their privacy than free individuals, perhaps there is no difficulty with conducting HIV tests on individuals who have not been convicted. This argument, however, does not square with the rationales generally advanced for suspicionless HIV testing of accused rapists and others. The reduction in detainees' privacy expectations extends only as far as the necessities of jail or prison security and administration. ${ }^{297}$

The arguments for HIV testing of accused sex offenders and prostitutes, on the other hand, rely upon victims' rights and public health rationales. While one might construct an argument for HIV testing of pretrial detainees, it would be difficult to extend it to those accused of prostitution, for instance, because inany prostitutes are never in fact held in jail or prison. Moreover, an HIV testing requirement in the jail or prison setting would run up against the fact that correctional officials have a responsibility to prevent sexual contact (and most other forms of

295. The purpose most commonly advanced to support involuntary HIV testing of accused or convicted sex offenders is to give the victims of their conduct information that they might use in making medical and lifestyle decisions. Another frequently stated purpose is to guard against the spread of HIV by the accused or convicted offender himself. See infra note 299 and accompanying text. While the latter purpose might be served by mandatory testing of those only accused of crimes, it would be served equally well by blanket testing of the entire sexually active population.

296. See Bell v. Wolfish, 441 U.S. 520, 545-46 (1979).

297. See id. at 546 ("[M]aintaining institutional security and preserving internal order and discipline are essential goals that may require limitation or retraction of the retained constitutional rights of ... pretrial detainees."); id. at 558-60 (upholding visual body cavity searches of detainees on basis of "significant and legitimate security interests of the institution"). 
activity that can transmit HIV) among prisoners and detainees. Thus, a claim that administrative concerns render such tests necessary seems dubious. In any event, the reduced Fourth Amendment rights of pretrial detainees cannot justify the kind of suspicionless testing programs at issue in this Comment.

\section{E. After Blameworthiness: A Word About Balancing in HIV Testing}

In dealing with the categories of persons who have been convicted of acts that are criminally blameworthy, it is tempting to produce verbal formulas to describe the additional scrutiny that a testing program would have to withstand in order to be constitutional. We could, for instance, say that HIV testing of convicted rapists or child molesters is permissible so long as it is reasonably designed to serve important governmental interests, and so long as the testing is conducted in such a way as to safeguard the subjects' health and protect the privacy of the results. Similarly, we might say that HIV testing of prostitutes is only allowable if it is strictly necessary to serve compelling government interests; we might furthermore require of such testing even more stringent procedural protections than in the case of sex offenders.

What is more important than verbal incantations, however, is the central idea that as blameworthiness decreases, the showing necessary to justify a testing program increases. As an intuitive matter, we are inclined to accept lesser showings when the person to be tested has committed a violent sexual assault, perhaps because we see the testing as deserved, or as a form of restitution to the victim of the crime. To a lesser extent, the same is true in the case of persons who have bitten or otherwise assaulted police officers. Because of the victimless character of prostitution, ${ }^{298}$ these considerations compel us to demand more on the government side of the balance when the subject is a convicted prostitute.

This Comment does not offer a detailed account of the discretionary balancing that courts should undertake in those cases where blameworthy acts render involuntary drug or HIV testing at least possibly permissible. The preceding Section sketches the general hierarchy of blameworthiness, and this Section has begun to indicate the corresponding showings of service to governmental interests and procedural protection necessary to justify testing. I add here only a few brief thoughts concerning the kinds of governmental interests usually advanced in support of HIV testing in particular.

The governmental interests that are most often said to be served by such testing are 1) providing the victim of the crime with information

298. See supra note 290 and accompanying text. 
vital to her health and peace of mind, and 2) curtailing HIV's spread through the population. ${ }^{299}$ In order for the first to be effectively served, the crime of which the offender has been convicted must be one that carries a realistic danger of HIV transmission. This category would certainly include any crimes involving penile penetration into the vagina, anus, or mouth, but it would not include some of the crimes listed in the Washington statute at issue in In re Juveniles $A, B, C, D, E .^{300}$ It also would not include biting a police officer, as the best available medical evidence indicates that HIV simply is not transmitted via saliva. ${ }^{301}$

The second governmental interest proposed above-that of promoting public health by curtailing the spread of HIV-might be served either by preventing the offender from communicating the virus to anyone else, or by preventing the victim from doing so, assuming she has indeed been infected. As to the former, if the tests are intended to prevent the offender from passing HIV to others after he is released from prison, then they would run afoul of the requirement that the involuntary tests be addressed to harms springing from the blameworthy action itself. $^{302}$ If, on the other hand, the tests are meant to prevent the sex offender from communicating the virus to others while imprisoned for the offense, then the threshold is cleared and testing may be permissible.

Any positive effect that such tests might have on HIV prevention within the prison setting, however, would depend either upon the offender himself being willing to receive treatment and modify his behavior, or upon institutional measures taken to isolate the offender or otherwise prevent him from spreading HIV. The first of these possibilities seems remote; presumably, an offender who refuses to consent to HIV testing has made a decision to forgo any benefits to himself or others that might spring from knowing whether or not he is infected. The second possibility likely raises serious civil rights issues. It is beyond the scope of this Cominent to address the question whether a prison inmate who tested positive for HIV might permissibly be isolated from the general prison population or subjected to other restrictions on conduct or movement not generally applied to other prisoners.

299. See, e.g., Virgin Islands v. Roberts, 756 F. Supp. 898, 903 (D.V.I. 1991).

300. See In re Juveniles A,B,C,D,E, 847 P.2d 455, 461 (Wash. I993) (upholding the statute's application even in the case of crimiual acts, such as touching and kissing minors, that "involve no passing of bodily fluids"). For a discussion of the Juveniles case, see supra notes 198-204 and accompanying text.

301. See Barlow v. Ground, 943 F.2d 1132, 1138 (9th Cir. 199I) (citing Center for Disease Control report that "the potential for transmitting the virus by saliva is 'remote." (citation omitted)); Johnetta J. v. Municipal Court, 267 Cal. Rptr. 666, 670-71 (Ct. App. 1990); Syring v. Tucker, 498 N.W.2d 370, 373 (Wis. 1993) (finding that "apparently there has not been a documented case of transmission via saliva").

302. See supra note 278 and accompanying text. 
Testing the sex offender might give the victim a limited amount of useful information to help her make decisions about her own treatment and future behavior, thereby advancing the goal of curtailing the virus' spread. Although it is true that a test of the offender can never resolve fully the question of whether the victim is infected, it can at least tell her that she has been exposed to the virus. ${ }^{303}$ That knowledge might legitimately lead the victim to modify her behavior, either by abstaining from sexual activity or by using more protective measures and informing her sexual partners of her exposure. Certainly the mere possibility of exposure should lead to some level of precaution, but the certainty of it could make a meaningful difference to the public health goal.

It is a close question, then, whether the public health and victim information goals can justify HIV testing of convicted sex offenders. Assuming that the victim is alive and wishes to know her attacker's test results, the balance might tip slightly in the direction of upholding testing.

The same conclusion does not follow in the case of convicted prostitutes. As with sex offenders, any curtailment of the spread of HIV via the offenders themselves would depend upon the prostitutes' willingness to seek treatment and change their behavior. Unless society is willing to make treatment mandatory and punish what it sees as irresponsible actions by those infected with $\mathrm{HIV},{ }^{304}$ forced testing of prostitutes will not prevent the spread of HIV any better than would voluntary testing and treatment. Similarly, tests might give the other parties-the "johns"information concerning their own exposure to the virus. Very few would argue, however, that those who patronize prostitutes have the kind of moral entitlement to peace of mind that victims of rape and other sex crimes do. ${ }^{305}$ Because of the far lower level of blameworthiness associated with prostitution, the benefits of informing johns of their exposure to the virus almost certainly do not justify involuntary testing.

\section{CONCLUSION}

Ultimately, what is at issue in drug and HIV testing cases is whether, and when, to subject individuals to intrusion, indignity, and other negative consequences in order to serve interests deemed important to the public good. As it is currently applied, the special needs analysis answers that question expansively. It approves invasive searches designed

303. See supra notes $242-243$ and accompanying text.

304. This latter choice would make any compelled HIV tests look a great deal more like searches designed to uncover evidence of criminal activity. Such tests, therefore, would probably be subject to the Warrant Clause of the Fourth Amendment.

305. This claim is true despite one court's characterization of johns as "victims." See People v. Adams, 597 N.E.2d 574, 581 (Ill. 1992); see also supra note 290. 
to uncover intimate information fraught with the most serious of consequences, all upon the strength of a balancing test that tends inexorably to overvalue governinental interests at the expense of individual privacy.

The special needs analysis seems inevitably to assume that the purpose of the Fourth Amendinent is itself administrative. It views the Amendment as a device for determining what searches and seizures might be necessary or helpful to carry out governmental designs. This Comment proceeds from a different view of the Fourth Ainendment, one that understands the Amendinent's most central function to be safeguarding individuals from intrusions instigated by overzealous government actors. ${ }^{306}$ On this view, within the inherent tension between a people and their government, it is the people who most frequently need protecting. ${ }^{307}$

Beginning from that view of the Fourth Amendment, I propose an analysis of drng and HIV testing scheines that concentrates principally upon the blameworthmess of the actions or conditions that might incur testing. This approach resonates with deeply held ideas of individual autonomy and limited government. ${ }^{308}$ It insists that suspicionless, invasive searches must not be visited upon mnocent persons and demands that they be imposed upon the guilty only after intense scrutiny of the purposes they serve, their necessity to those purposes, and the procedures by which they are conducted. It pulls individual privacy interests out from the morass of an amorphous balancing analysis, preventing courts from trading them off against other concerns. In short, it allows the Fourth Amendment to perform in this arena the function I believe it ought to perform: to protect individuals from governmental intrusions in all but a few cases.

This solution is very clearly strong medicine. It would mean that the government could not require suspicionless drug or alcohol testing of such groups as airline pilots and the Secret Service agents who guard the President of the United States. I am content with those implications, however, because I believe that a combination of voluntary testing,

306. See, e.g., Amsterdam, supra note 21, at 400 ("I believe [the authors of the Bill of Rights] meant to guarantee to their survivors the right to live as free from every interference of government agents as our condition would permit."); Clancy, supra note 223, at 63 I (invoking individualized suspicion as "[a] bulwark against relentless expansion of governmental intrusion into all aspccts of life").

307. Cf. Lewis R. Katz, In Search of a Fourth Amendment for the Twenty-First Century, 65 IND. L.J. 549, 590 (I990) (arguing that the Fourth Amendment should serve to protect "individual freedom and autonomy"); Maclin, supra note 23, at 20I ("[T] $]$ he central meaning of the Fourth Amendment is distrust of police power and discretion.").

308. Cf. Amsterdam, supra note 21, at 353 (calling " $[t]$ he Bill of Rights in general and the Fourth Amendment in particular a profoundly anti-government docuinent"); Katz, supra note 307, at 554 \& n.27 (discussing "the other great theme of the fourth amendinent: that ours is a system of limited government"). 
education and treatment, supervisor training, suspicion-based testing, and stern sanctions for repeated violations of drug and alcohol rules can provide a considerable level of safety in these sensitive positions.

When all is said and done, placing blaineworthiness at the forefront of judicial analysis of involuntary drug and HIV testing represents a vast improvement over the current approach. It takes better account of the great differences ainong the factual situations in which such testing takes place, and it coinports with deep moral intuitions about who should and should not have their interests invaded. Most of all, it allows the Fourth Amendinent to play its proper role as a bulwark against government intrusion into the lives of individuals. 
CALIFORNIA LAW REVIEW 